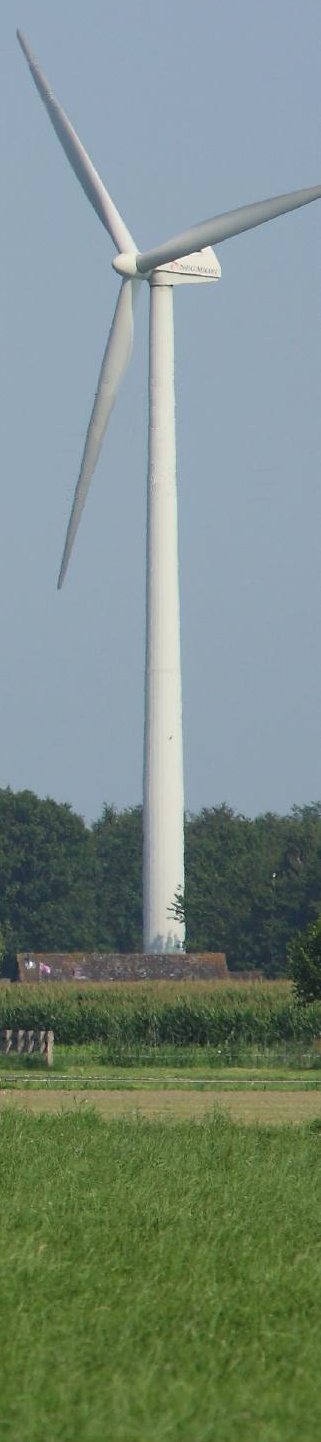

\title{
Verkenning vruchtwisselingsopties met voedergewassen op melkveebedrijven
}

W. van Dijk ${ }^{1}$ | M.W.J. Stienezen ${ }^{1}$ | R.L.G.Zom ${ }^{1}$ \& R.Y. van der Weide ${ }^{1}$

${ }^{1}$ Wageningen University \& Research 


\section{Verkenning vruchtwisselingsopties met voedergewassen op melkveebedrijven}

W. van Dijk1, M.W.J. Stienezen1, R.L.G.Zom1, R.Y. van der Weide1

1 Wageningen University \& Research

Dit onderzoek is uitgevoerd door Wageningen University \& Research in samenwerking met bedrijfslevenpartners Agrifirm, Bionext, DLF, DSV Zaden Nederland, ForFarmers Group, Limagrain Nederland, LTO Nederland, NMB, Plantum en ZuivelNL in het kader van het publiek-private samenwerkingsprogramma "Ruwvoerproductie en Bodemmanagement" (www.ruwvoerenbodem.nl), medegefinancierd door het Ministerie van Landbouw, Natuur en Voedselkwaliteit via de topsector Agri \& Food (TKI-AF-15284 en TKI-AF-15102) (BO-31.03-010-001, BO-31.03008-007). 
Van Dijk, W., M.W.J. Stienezen, R.L.M Zom \& R.Y. van der Weide, 2020. Verkenning vruchtwisselingsopties met voedergewasssen op melkveebedrijven. Wageningen Research, Rapport WPR-844

Dit rapport is gratis te downloaden op https://doi.org/10.18174/530095

Trefwoorden: voedergewassen, vruchtwisseling, bouwplan, wintergewas, ruw eiwit, DVE, VEM, effectieve organische stof

(c) 2020 Wageningen, Stichting Wageningen Research, Wageningen Plant Research, Business unit Open Teelten, Postbus 430, 8200 AA Lelystad; T 03002911 11; www.wur.nl/plant-research

KvK: 09098104 te Arnhem

VAT NL no. 8113.83.696.B07

Stichting Wageningen Research. Alle rechten voorbehouden. Niets uit deze uitgave mag worden verveelvoudigd, opgeslagen in een geautomatiseerd gegevensbestand, of openbaar gemaakt, in enige vorm of op enige wijze, hetzij elektronisch, mechanisch, door fotokopieën, opnamen of enige andere manier zonder voorafgaande schriftelijke toestemming van Stichting Wageningen Research.

Stichting Wageningen Research is niet aansprakelijk voor eventuele schadelijke gevolgen die kunnen ontstaan bij gebruik van gegevens uit deze uitgave.

Foto omslag: Jantine van Middelkoop, Wageningen University \& Research 
$\begin{array}{ll}\text { Samenvatting } & 3\end{array}$

$\begin{array}{ll}\text { Inleiding } & \mathbf{5}\end{array}$

2

$\begin{array}{ll}\text { Varianten en uitgangspunten } & 7\end{array}$

$\begin{array}{lll}2.1 & \text { Continuteelt mais met wintergewas } & 7\end{array}$

$\begin{array}{ll}2.1 .1 \text { Varianten } & 7\end{array}$

2.1.2 Uitgangspunten berekeningen $\quad 8$

2.2 Mais in vruchtwisseling $\quad 10$

2.2.1 Bouwplannen 10

2.2.2 Uitgangspunten en berekeningen 11

3

$\begin{array}{lr}\text { Resultaten } & 16\end{array}$

3.1 Continuteelt mais met wintergewas $\quad 16$

3.1.1 Aanvoer effectieve organische stof 16

$\begin{array}{ll}3.1 .2 \text { Financiële effecten } & 16\end{array}$

3.2 Vruchtwisseling met andere gewassen 18

3.2.1 Aanvoer effectieve organische stof 18

$\begin{array}{ll}3.2 .2 \text { Voederwaarde opbrengst } & 20\end{array}$

$\begin{array}{ll}\text { 3.2.3 Melkproductie uit eigen voer } & 22\end{array}$

$\begin{array}{lr}\text { Discussie en conclusies } & 28\end{array}$

$\begin{array}{lll}4.1 & \text { Discussie } & 28\end{array}$

4.2 Conclusies $\quad 31$

4.2.1 Continuteelt mais met wintergewassen 31

4.2.2 Vruchtwisseling met andere gewassen 31

$\begin{array}{ll}\text { Literatuur } & 34\end{array}$

Bijlage 1 Voederwaardekenmerken 36

$\begin{array}{lll}\text { Bijlage } 2 & \text { Verzadigingswaarde } & 38\end{array}$

Bijlage $3 \quad$ Uitgangspunten berekeningen rantsoenen melkvee 39 


\section{Samenvatting}

Binnen het PPS-project Ruwvoederproductie en bodemmanagement is een deskstudie uitgevoerd om te verkennen of de voederwaardeproductie (energie en eiwit) en de organische stofvoorziening op melkveebedrijven kan worden verbeterd door aanpassing van het huidige bouwplan met wintergewassen en/of nieuwe hoofdgewassen.

\section{Tussengewasvarianten}

Specifiek voor mais in continuteelt, waarin jaar op jaar mais wordt verbouwd, is gekeken wat de teelt van vroege maisrassen in combinatie met verschillende wintergewassen en het gebruik hiervan betekent voor het teelt saldo en de aanvoer van effectieve organische stof (EOS). Hiervoor is een later maisras met een matig ontwikkeld wintergewas dat werd ondergewerkt, vergeleken met varianten met vroege maisrassen en een goed ontwikkeld wintergewas dat werd ondergewerkt of geoogst voor het onderwerken. In de situaties dat het wintergewas direct werd ondergewerkt zijn ondergezaaid gras en nagezaaide winterrogge met elkaar vergeleken. Werd het wintergewas geoogst dan is ondergezaaid gras vergeleken met een nagezaaid mengsel van rogge met wintererwt.

Het telen van een wintergewas waarbij wordt uitgegaan van een vroegere maisoogst leidt op de korte termijn tot een lager financieel saldo van de mais. Het tijdig inwerken van het wintergewas (functie als vanggewas) is daarbij gunstiger dan het oogsten ervan (functie als tussengewas). Dit is vooral een gevolg van de extra oogstkosten van het tussengewas. De effecten van de oogst van het tussengewas op de voerkosten zijn buiten beschouwing gelaten.

Het inwerken van het wintergewas geeft een hogere EOS-aanvoer. Op de langere termijn heeft dit een positief effect op de organische stofvoorziening.

\section{Vruchtwisseling met andere gewassen}

Verder zijn op bedrijfsniveau bouwplannen doorgerekend voor een bedrijfsareaal van 60 ha. Als referentie is ervan uitgegaan dat $80 \%$ van het bedrijfsareaal uit gras bestaat en $20 \%$ uit mais (conform derogatie-eis). Hierbij is onderscheid gemaakt tussen continuteelt van gras en mais en een situatie waar een deel van het gras in wisselbouw ligt met de mais: 60\% permanent grasland, 20\% tijdelijk grasland en $20 \%$ mais. In het wisselbouwdeel wordt 3 jaar gras afgewisseld met 3 jaar mais. Vervolgens zijn varianten bekeken, waarbij 1) een deel van de mais is vervangen door voederbieten, triticale of veldbonen, 2 ) het tijdelijk grasland is vervangen door een tijdelijk gras + rode klaver en 3 ) het tijdelijk grasland is vervangen door luzerne.

De bouwplanvarianten zijn beoordeeld op aanvoer van hoeveelheid effectieve organische stof, voederwaardeproductie (energie (Voeder Eenheid Melk,VEM), ruw eiwit (RE), darmverteerbaar eiwit (DVE)) en de potentie voor de melkproductie. De potentie voor de melkproductie is in kaart gebracht door de hoeveelheid melk te berekenen die met de gemiddelde Nederlandse koe (CBS 2018) kan worden geproduceerd op basis van de eigen geproduceerde voederwaarde, en te berekenen hoeveel VEM en DVE hierbij aangekocht moeten worden en in welke verhouding.

Voederwaarde- en melkproductie

Wisselbouw mais en gras versus continuteelt

Het toepassen van wisselbouw in plaats van continuteelt leidt tot een hogere voederwaardeproductie als gevolg van een hogere maisopbrengst. De totale melkproductie is hierdoor logischerwijs hoger dan bij een situatie met continuteelt.

Vervanging mais door voederbieten, triticale en veldbonen Bij een aantal varianten is in het bouwlanddeel ( $20 \%$ van het bedrijfsareaal) $1 / 3$ van de mais vervangen door voederbieten of triticale. Daarnaast zijn varianten bekeken waarbij $2 / 3$ van de mais is vervangen: door voederbiet + triticale of voederbiet + veldboon. Al deze varianten zijn vergeleken met een referentievariant met $100 \%$ mais op het bouwland. Het grasdeel was overal gelijk, namelijk $20 \%$ tijdelijk grasland en $60 \%$ permanent grasland. 
Vervanging van $1 / 3$ van de mais door voederbieten geeft een hogere VEM-, RE- en DVE-productie, terwijl vervanging van een $1 / 3$ van de mais door triticale leidt tot een lagere VEM-, RE- en DVEproductie. Vervanging van $2 / 3$ van de mais door zowel voederbieten én veldbonen geeft een lagere VEM-productie zowel ten opzichte van $1 / 3$ van de mais vervangen door voederbiet als $100 \%$ mais. De RE-productie is hoger t.o.v. zowel $1 / 3$ van de mais vervangen door voederbiet als $100 \%$ mais. De DVE-productie is lager dan bij $1 / 3$ van de mais vervangen door voederbiet, maar hoger dan bij $100 \%$ mais.

Bij alle genoemde varianten daalt de totale melkproductie t.o.v. 100\% mais. Wel is de hoeveelheid geproduceerde melk van het eigen geteelde voer hoger bij vervanging van $1 / 3$ van de mais door voederbiet, maar lager bij vervanging van $1 / 3$ van de mais door triticale en vervanging van $2 / 3$ door de mais door voederbiet én veldboon.

Vervanging tijdelijk grasland door gras-rode klaver

In deze variant is het tijdelijke gras vervangen door een gras-rode klavermengsel. In het bouwlanddeel is niets veranderd ( $100 \%$ mais). Bij deze variant daalt de VEM- en DVE-productie. De RE-productie is wel hoger. De lagere VEM- en DVE-productie zijn een gevolg van de lagere VEM- en DVE-gehalten in het gras rode klavermengsel. Dit wordt onvoldoende gecompenseerd door de wat hogere drogestofproductie van het gras-rode klavermengsel.

De totale melkproductie in de variant met het gras-rode klavermengsel is hoger dan bij tijdelijk grasland. De hoeveelheid geproduceerde melk van het eigen geteelde voer is echter lager, maar anders dan bij de hierboven besproken bouwplanvarianten, is het hier wel mogelijk om via het aangekochte voer een hogere melkproductie te realiseren dan wanneer alleen gras zou worden geteeld.

Vervanging tijdelijk grasland door luzerne

Bij deze variant is het tijdelijke grasland vervangen door luzerne. Deze vergelijking is gedaan bij een situatie waarin het bouwlanddeel bestond uit $1 / 3$ mais, $1 / 3$ voederbieten en $1 / 3$ triticale. De reden hiervoor was om ook een variant mee te nemen met een hoge diversiteit aan gewassen.

Vervanging van het gras door luzerne leidt tot een lagere VEM- en DVE-productie, terwijl de REproductie hoger is. De totale melkproductie is hoger, maar de hoeveelheid melk geproduceerd van het voer van het eigen geteelde voer is lager. Er is dus meer aangekocht voer nodig om deze hogere melkproductie te realiseren.

Verhouding geteelde energie en eiwit

Deze studie laat de potentie van verschillende gewassen voor de melkproductie zien maar is geen optimalisatie studie. Er is bij het inrichten van de bouwplannen niet gestuurd op de verhouding waarin eiwit (DVE) en energie (VEM) werden verbouwd. De bouwplannen met de hoogste VEM-productie en de laagste DVE-productie realiseren de hoogste melkproductie. De voerproductie op deze bedrijven ligt voor een groter deel buiten het eigen bedrijf (hogere aankoop DVE).

\section{Organische stofvoorziening}

De verschillen in totale EOS-aanvoer tussen de bouwplannen zijn gering. Dat komt door het hoge aandeel gras ( $80 \%$ in de meeste rotaties) dat een hoge aanvoer van EOS geeft op gewasniveau. In vergelijking met de situatie met alleen mais en gras neemt de EOS-aanvoer licht toe in de varianten met andere bouwlandgewassen. De aanvoer is het hoogst in de rotaties met triticale.

Hoewel de totale EOS-aanvoer weinig verschilt tussen de bouwplannen, verbetert bij de bouwplanvarianten met gras in wisselbouw wel de situatie voor het bouwland. De EOS-aanvoer voor het wisselbouw-deel van het bedrijf is hoger dan bij de continuteelt van mais. 


\section{Inleiding}

\section{Aanleiding}

Het PPS-project Ruwvoederproductie en bodemmanagement richt zich op verbetering van de Nederlandse ruwvoederproductie en het bodemmanagement, in samenhang met een verlaging van de milieubelasting. In het werkpakket "Bouwplanopbrengst - en optimalisatie" wordt nagegaan hoe vruchtwisseling hieraan een bijdrage kan leveren. In de huidige melkveehouderij bestaat de ruwvoerproductie hoofdzakelijk uit grasland en snijmaïs. In een belangrijk deel van de praktijk wordt de maïs bovendien in continuteelt verbouwd. Verandering van deze situatie is op een aantal manieren mogelijk, bijvoorbeeld door:

- $\quad$ Het telen van een vanggewas/tussengewas tussen twee maïsteelten in of

- V Vruchtwisseling van snijmaïs met andere gewassen (gras, andere voedergewassen, akkerbouwgewassen).

Zowel vanuit de sector als de overheid is er de wens om beter te voorzien in de eigen voederproductie inclusief de benodigde lokale eiwitproductie (Visie Grondgebondenheid melkveehouderijsector, Visie Kringlooplandbouw LNV). Dit kan ook leiden tot andere bouwplannen en vruchtwisselingen dan de huidige.

\section{Doel en afbakening}

Het doel van deze deskstudie is om te verkennen of de voederwaardeproductie (energie en eiwit) en de organische stofvoorziening op melkveebedrijven kan worden verbeterd door aanpassing van het huidige bouwplan via tussengewassen en/of nieuwe hoofdgewassen.

De studie beperkt zich tot vruchtwisseling met voedergewassen uitgaande van melkveebedrijven waar geen akkerbouwtak aanwezig is. Gemengde bedrijven of situaties van gezamenlijk grondgebruik tussen een melkveehouder met een akkerbouwer, waarbij ook akkerbouwgewassen worden geteeld op het melkveebedrijf en de melkveehouder voer teelt op het akkerbouwbedrijf, worden buiten beschouwing gelaten. Dit heeft reeds de aandacht binnen andere projecten.

\section{De aanpak}

In de studie zijn diverse vruchtwisselingsvarianten doorgerekend, waarbij onderscheid is gemaakt tussen situaties met tussengewassen waarbij nog wel steeds elk jaar mais wordt geteeld en situaties met vruchtwisseling van gras, mais en andere gewassen. De tussengewasvarianten sluiten aan op de binnen de PPS uitgevoerde veldexperimenten.

De vruchtwisselingsvarianten zijn in overleg met de deelnemende bedrijfslevenpartners in de PPS vastgesteld. Een aantal van deze varianten kunnen binnen de huidige wet- en regelgeving niet worden uitgevoerd. Deze zijn in deze studie opgenomen om de landbouwkundige waarde te verkennen. De scenario's worden beschouwd op voederproductie, economie (alleen vanggewas/tussengewasscenario's) en organische stofvoorziening.

\section{Voederproductie}

De bouwplannen worden beoordeeld op de totale bouwplanopbrengst van droge stof, voedereenheid melk (VEM), ruw eiwit (RE) en darm verteerbaar eiwit (DVE). Daarnaast wordt inzichtelijk gemaakt hoeveel melk uit het eigen voer kan worden geproduceerd en wat de samenstelling van het aan te kopen krachtvoer moet zijn.

\section{Economie}

De varianten waarbij de maïs in continuteelt wordt geteeld in combinatie met een vanggewas/tussengewas worden beschouwd de op economische aspecten financiële opbrengst, kosten en saldo. 
Organische stof

De organische stof voorziening van de bouwplannen wordt beschouwd aan de hand van de aanvoer van Effectieve Organische Stofbalans (EOS) uit gewasresten en dierlijke mest.

De EOS is de organische stof die een jaar na toediening nog aanwezig is en een bijdrage levert aan de humusopbouw in de bodem.

\section{Leeswijzer}

In hoofdstuk 2 zijn de bouwplannen en de daarbij gehanteerde uitgangspunten beschreven. Hoofdstuk 3 geeft de resultaten weer. Het rapport wordt afgesloten met een discussie van de resultaten en de conclusies in hoofdstuk 4. 


\section{Varianten en uitgangspunten}

\subsection{Continuteelt mais met wintergewas}

\subsubsection{Varianten}

Een aanzienlijk deel van de in Nederland geteelde maïs wordt in continuteelt verbouwd. Een wintergewas, een gewas dat na de oogst van de maïs wordt gezaaid, kan de stikstof (N) uitspoeling verminderen en extra organische stof leveren. Een wintergewas dat in het voorjaar wordt ondergewerkt wordt in deze studie een vanggewas genoemd. Een wintergewas dat in het voorjaar wordt geoogst voordat het wordt ingewerkt wordt in deze studie een tussengewas genoemd. Op zanden lössgronden is het wettelijk verplicht om na mais een wintergewas te zaaien, maar de ervaring is dat in gemiddelde jaren de ontwikkeling vaak tegenvalt door de relatief late zaai van het wintergewas als gevolg van een late oogst van de mais. Deze situatie is vergeleken met varianten waarin een maïsras is gezaaid dat eerder kan worden geoogst (vroeg ras) waardoor betere ontwikkelmogelijkheden voor het wintergewas ontstaan. De varianten die zijn onderzocht zijn die van een vroeg maïsras met winterrogge en grasonderzaai die worden ingewerkt (ingewerkt vanggewas) en met grasonderzaai en een mengsel van rogge en wintererwten die worden geoogst als tussengewas (geoogst tussengewas). De doorgerekende varianten van maïs met een wintergewas staan in Tabel 1. $\mathrm{Er}$ is uitgegaan van een situatie op zandgrond in Centraal-, Oost- en Zuid-Nederland, hier wordt de meeste snijmais geteeld.

De referentievariant betreft een situatie waarin een hoge maïsopbrengst centraal staat. Er is onderscheid gemaakt tussen rogge als vanggewas (Ref1) en grasonderzaai als vanggewas (Ref2). In het eerste geval moet het vanggewas voor 1 oktober worden gezaaid en is uitgegaan van een vroegere maisoogst met een lagere opbrengst, in het tweede geval mag de mais later dan 1 oktober worden geoogst en kan een wat hogere maisopbrengst worden gerealiseerd. Bij Ref2 is uitgegaan van een goede veldopbrengst van gemiddeld 17 ton drogestof per ha (Anonymus, 2019c). Vanuit dit opbrengstniveau zijn de opbrengsten van de andere varianten afgeleid op basis van zaai- en oogsttijd ten opzichte van Ref2. Hierbij is gebruik gemaakt van resultaten van rassenproeven en een eerdere studie naar teeltvervroeging bij mais (Verhoeven et al., 2011).

De vanggewassen worden in de referentievarianten in het voorjaar tijdig ondergewerkt (uiterlijk begin april) waardoor de inzaai van de maïs tijdig kan plaatsvinden en de $\mathrm{N}$-nalevering uit het vanggewas op tijd op gang komt. Door de relatief late zaai in het najaar en het tijdig vernietigen in het voorjaar is de ontwikkeling van het vanggewas beperkt, er is uitgegaan van een nalevering van $10 \mathrm{~kg} \mathrm{~N}$ per ha voor beide referentievarianten.

Door een vroeger maïsras te zaaien is er meer ruimte voor het wintergewas. Het wintergewas kan worden ingewerkt voor organische stof en stikstofnalevering (varianten Inwerk1 en Inwerk2) of in het voorjaar, voor het zaaien van de maïs, worden geoogst (varianten Oogst1 en Oogst2). In beide gevallen is de maïsopbrengst lager dan in de referentievarianten.

Door het oogsten van het tussengewas kan het opbrengstverlies van de maïs, geheel of gedeeltelijk, worden gecompenseerd. Bij grasonderzaai als tussengewas is uitgegaan van een oogsttijdstip dat samenvalt met de grasoogst (1e week mei) zodat het daarmee kan worden ingekuild. Er is uitgegaan van een veldopbrengst van 1,3 ton per ha. Deze is gebaseerd op een gemiddelde wintertemperatuur en het niet bemesten van het tussengewas. Bij een mengsel van rogge en wintererwten als tussengewas is uitgegaan van een latere oogst (3e week mei), omdat het veldonderzoek liet zien (Stienezen et al., 2019) dat met dit mengsel dan een hoge opbrengst (3-4 ton per ha) kon worden gerealiseerd.

Bij de inwerkvarianten is uitgegaan van een stikstofnalevering van $25 \mathrm{~kg} \mathrm{~N}$ per ha, bij de oogstvarianten is geen nalevering ingerekend. Dit is conform het bemestingsadvies (Anonymus, 2019d). 
Tabel 1 Doorgerekende varianten van mais met wintergewas op zandgrond representatief voor Centraal-, Oost- en Zuid-Nederland.

\begin{tabular}{|c|c|c|c|c|c|c|c|}
\hline \multirow[t]{2}{*}{ Variant } & \multicolumn{3}{|c|}{ Maïs } & \multicolumn{2}{|c|}{ Wintergewas } & \multirow{2}{*}{$\begin{array}{l}\text { Drogestof- } \\
\text { opbrengst } 1\end{array}$} & \multirow{2}{*}{$\begin{array}{l}\begin{array}{l}\mathrm{N} \text {-nalevering } \\
\text { vanggewas }\end{array} \\
\text { (kg N/ha) }\end{array}$} \\
\hline & Rastype & Zaaitijd & Oogsttijd & Type & $\begin{array}{c}\text { Inwerken/ } \\
\text { oogsten }\end{array}$ & & \\
\hline Ref1 & Midden-vroeg & 20 april & 25 sep & Rogge & Inwerken & 16.3 & 10 \\
\hline Ref2 & Midden-laat & 20 april & 10 okt & $\begin{array}{c}\text { Gras- } \\
\text { onderzaai }\end{array}$ & Inwerken & 17.0 & 10 \\
\hline Inwerk1 & Vroeg & 20 april & $15 \mathrm{sep}$ & Rogge & Inwerken & 15.5 & 25 \\
\hline Inwerk2 & Midden-vroeg & 20 april & 25 sep & $\begin{array}{c}\text { Gras- } \\
\text { onderzaai }\end{array}$ & Inwerken & 16.3 & 25 \\
\hline Oogst1 & Ultravroeg & 20 mei & 25 sep & $\begin{array}{c}\text { Rogge }+ \\
\text { erwt }\end{array}$ & Oogsten & $13.6+4.0$ & 0 \\
\hline Oogst2 & Vroeg & 10 mei & 25 sep & $\begin{array}{c}\text { Gras- } \\
\text { onderzaai }\end{array}$ & Oogsten & $14.5+1.3$ & 0 \\
\hline
\end{tabular}

1 Veldopbrengst, bij Oogst1 en Oogst2 opbrengst van snijmaïs en tussengewas

2 Hoeveelheid stikstof nalevering uit vanggewas dat is ingerekend t.b.v. bemesting maïs

\subsubsection{Uitgangspunten berekeningen}

Bij de economische berekeningen is de veldopbrengst (Tabel 1) gecorrigeerd voor drogestofverliezen bij inkuilen. Bij snijmaïs is uitgegaan van een verlies van 5\% (Anonymus, 2019c) en bij de tussengewassen gras en rogge-erwtenmengsel van respectievelijk 15 en 10\% (De Boer et al., 2006). Bij snijmaïs is een voederkwaliteit van 980 VEM en 52 gram DVE per kg drogestof (na inkuilen) gehanteerd (www.handboeksnijmais.nl) en bij de tussengewassen is uitgegaan van een voederwaarde van 875 VEM en 60 gram DVE per kg drogestof. Voor het rogge-erwten-mengsel zijn deze waarden gebaseerd op meetgegevens van proefvelden van Nordic Maize Breeding(pers. mededeling Grietje Raaphorst), voor de grasonderzaai is uitgegaan van standaardgehalten in kuilgras.

Vervolgens is de financiële opbrengst berekend op basis van een kVEM-prijs van $€ 0.175$ en een DVEtoeslag van €0.64 per kg DVE (Anonymus, 2019b; gemiddelde van de afgelopen twaalf maanden). Voor de kosten van bewerkingen en producten (zaaizaad, meststoffen, herbiciden) is meestal uitgegaan van de KWIN-Veehouderij (Anonymus, 2016b) Ttabel 2). Alleen wanneer geen informatie in de KWIN beschikbaar was zijn de kosten ingeschat op basis van ervaringen van lopende of recent afgesloten projecten. Bij de bewerkingen is uitgegaan van uitvoering in loonwerk.

Bij de bemesting van de maïs is bij alle varianten uitgegaan van een mestgift van 35 ton rundveedrijfmest per ha (volvelds toegediend) aangevuld met $30 \mathrm{~kg} \mathrm{~N}$ per ha toegediend als rijenbemesting. Deze bemesting komt overeen met de gebruiksnorm van werkzame $\mathrm{N}$ van $112 \mathrm{~kg} \mathrm{~N}$ per ha voor zuidelijk zand. Bij een N-bemesting lager dan het bemestingsadvies (Anonymus, 2019d) is de opbrengst en de $\mathrm{N}$-opname van de mais gecorrigeerd volgens de responscurves zoals afgeleid in Van Dijk et al. (2007). Hiermee is rekening gehouden met de stikstoflevering vanuit het wintergewas (Tabel 1). Hierbij is ervan uitgegaan dat de opbrengsten zoals vermeld in Tabel 1 worden behaald bij een bemesting volgens het advies (160 kg werkzame $\mathrm{N}$ per ha). Voor de stikstofgebruiksnorm is uitgegaan van de lage norm voor zuidelijk zand van $112 \mathrm{~kg} \mathrm{~N}$ per ha, omdat voor deze situatie de effecten van de stikstofnalevering van een tussengewas het sterkst zijn. In de discussie zal worden ingegaan op situaties voor overige zandgronden en op situaties waarin de dierlijke mest in de rij wordt toegediend.

$\mathrm{Er}$ is geen aanvullende fosfaatbemesting met kunstmest gegeven, omdat dat binnen de derogatievoorwaarden niet toegestaan is. Bij kali is de mestgift aangevuld met kunstmest tot een niveau waarbij de afvoer met geoogst gewas (mais en, indien van toepassing, tussengewas) wordt gecompenseerd. Op zandgrond wordt bij kali ook rekening gehouden met een onvermijdbaar kaliverlies van $50 \mathrm{~kg} \mathrm{~K} \mathrm{~K}_{2} \mathrm{O}$ per ha. Bij de inwerk- en oogstvarianten is ervan uitgegaan dan deze verliezen niet optreden door goed ontwikkelde wintergewassen. Bij de referentievarianten is uitgegaan 
van een onvermijdbaar verlies van $30 \mathrm{~kg} \mathrm{~K}{ }_{2} \mathrm{O}$ per ha, doordat het wintergewas minder sterk is ontwikkeld en minder kali heeft vastgelegd.

Voor de EOS-aanvoer-berekeningen is uitgegaan van de kengetallen (dierlijke mest en gewasresten) zoals weergegeven in het Handboek Bodem en Bemesting (Anonymus, 2019d). De EOS-aanvoer via het wintergewas is afhankelijk gesteld van de zaaitijd gerelateerde productie en het feit of het wintergewas wel of niet wordt geoogst.

Tabel 2 Gehanteerde kosten voor producten en bewerkingen (tenzij anders vermeld zijn de prijzen afkomstig uit de KWIN Veehouderij).

Prijs $(€ / h a)$

\section{Producten}

Zaaizaad

Mais

Tussengewas: Rogge, gras

Tussengewas: Rogge + wintererwten

\section{Bewerkingen}

Mais

Ploegen

Zaaibedbereiding

Mesttoediening (35 ton per ha a $€ 3 /$ ton)

Zaaien

Onkruidbespuiting

Hakselen + transport

Cultivateren

\section{Tussengewas}

Extra kosten zaaien (gecombineerd met cultivateren) 20

Onderzaai (gras)

Vernietigen in voorjaar $\quad 65$

Oogst

Maaien $\quad 26$

Wiersen $\quad 18$

$\begin{array}{lc}\text { Oprapen + transport } & 60 / 1072\end{array}$

$\begin{array}{ll}\text { Aanrijden + kuilverdeler } & 37 / 672\end{array}$

1 Gebaseerd op ervaringen Duurzaam bodembeheer mais

2 Kosten voor gras/rogge + erwten (lagere kosten bij gras door lagere opbrengst) 


\subsection{Mais in vruchtwisseling}

$\mathrm{Er}$ is tevens een verkenning uitgevoerd naar de effecten op het melkveebedrijf wanneer maïs in vruchtwisseling wordt verbouwd. Er is niet alleen gekeken naar de afwisseling van gras en mais, maar ook naar andere voedergewassen die interessant kunnen zijn voor het melkveebedrijf. De vruchtwisselingsvarianten zijn in samenwerking met de bedrijfslevenpartners in de PPS opgesteld. In eerste instantie is uitgegaan van een melkveebedrijf met $80 \%$ gras en $20 \%$ bouwland omdat dit de voorwaarden zijn om binnen de huidige wet- en regelgeving gebruik te kunnen maken van derogatie. De andere varianten zijn ingevuld vanuit de voorwaarde om meer eiwit op het eigen bedrijf te produceren en de inzet van vlinderbloemigen om de opbrengst en voederwaarde op peil te houden met minder input van stikstof. Hierbij is uitgegaan van landbouwkundige aspecten en daarom voldoen niet alle varianten aan de huidige wet- en regelgeving. In de berekeningen is uitgegaan van de goede landbouwpraktijk dat wil zeggen het volgen van de huidige standaarden zoals de bemestingsadviezen, teeltadviezen, tabellenboek voederwaarde en normen voor de voederwaarde voorziening van melkvee. Bij de beoordeling van de vruchtwisselingsvarianten (hierna bouwplan genoemd) is gekeken naar de totale voederwaardeproductie van het bouwplan (energie en eiwit), de potentie van het bouwplan voor de productie van melk uit de geteelde gewassen en de aanvoer van effectieve organische stof. Er is niet gekeken naar de economie van de bouwplannen. Voor de berekeningen is uitgegaan van een bedrijfsareaal van 60 ha.

\subsubsection{Bouwplannen}

In Figuur 1 zijn de doorgerekende bouwplannen schematisch weergegeven.

In de bouwplannen zijn ook gewascombinaties opgenomen die binnen de huidige wettelijke kaders niet toegestaan zijn, maar wel perspectief bieden. Bijvoorbeeld de teelt van luzerne en winterveldboon op zand- en lössgrond als in de herfst in te zaaien hoofdgewas na mais.

$\mathrm{Bij}$ de bemesting is ervan uitgegaan dat op het grasland 60 ton rundveedrijfmest per ha wordt toegediend (inclusief weidemest) en op het bouwland 40 ton per ha. Dit komt overeen met een fosfaataanvoer van 90 en $60 \mathrm{~kg}$ P2O5 per ha voor, respectievelijk, gras en mais. Dit is gelijk aan de fosfaatgebruiksnorm bij toestand neutraal. $\mathrm{Er}$ is in deze studie ervan uitgegaan dat aanvullend kunstmest stikstof is toegediend volgens het bemestingsadvies (Anonymus, 2019e).

Als referentie (bouwplan 1 ) is uitgegaan van een bedrijf met $80 \%$ permanent grasland en $20 \%$ permanent bouwland waar maïs in continuteelt wordt verbouwd. Na de maisteelt wordt winterrogge vóór 1 oktober als vanggewas ingezaaid. Het vanggewas wordt in het voorjaar ondergewerkt.

In het tweede bouwplan wordt de mais (3 aaneengesloten jaren) in afwisseling geteeld met 3-jarig gras. Door de wisselbouw resteert nog $60 \%$ permanent grasland. In de eerste twee maïsjaren is de teelt gelijk aan die in de continuteeltsituatie. In het laatste maisjaar wordt een vroeg maïs ras geteeld om tijdig het nieuwe grasland te kunnen inzaaien. Het nieuwe gras fungeert hier als vanggewas.

In de bouwplannen $3 \mathrm{t} / \mathrm{m} 7$ is er eveneens $40 \%$ wisselbouw van 3-jarig bouwland en 3-jarig grasland, maar is een deel van de mais vervangen door andere gewassen.

In bouwplan 3 en 4 wordt 1/3 van de mais vervangen door, respectievelijk, voederbieten en graan (triticale). De voederbieten worden gelijk na het scheuren van het gras geteeld, terwijl de triticale in het laatste bouwlandjaar wordt geteeld. Deze wordt na de oogst van de mais gezaaid en fungeert tevens als vanggewas. Door de vroege oogst van de triticale kan het nieuwe gras weer tijdig worden ingezaaid. Bij bouwplan 3 is onderscheid gemaakt tussen laat geoogste voederbieten (oogst begin november, $3 a$ ) en vroeg geoogste voederbieten (oogst eind september, 3b) die gelijk met de mais worden ingekuild. Door de vroegere oogst kan nog een vanggewas worden gezaaid na de bieten, maar is de voederwaardeopbrengst wel lager.

In de bouwplannen 5, 6 en 7 is 2/3 van de mais vervangen door andere gewassen: in het 1e jaar van de 3-jarige bouwlandperiode door voederbiet (late oogst) en in het derde jaar van de bouwlandperiode door, respectievelijk, triticale (bouwplan 5), winterveldbonen (bouwplan 6) of een mix van triticale en winterveldbonen (bouwplan 7). De laatstgenoemde variant is meegenomen, omdat de teelt van veldbonen dan gemakkelijker is, met name wat betreft onkruidbestrijding. 
In bouwplan 8 en 9 is het tijdelijke 3-jarige grasland vervangen door 3-jarige luzerne. In bouwplan 8 bestaat de 3-jarige bouwlandperiode uit voederbieten, mais en triticale, terwijl in bouwplan 9 de triticale is vervangen door winterveldbonen

In de bouwplannen 10 en 11 is het tijdelijke grasland vervangen door gras-rode klaver. In bouwplan 10 word deze geteeld in rotatie met mais en in bouwplan 11 in rotatie met mais en veldbonen. Beide bouwplannen zijn er op gericht om meer eiwit op eigen grond te verbouwen.

\begin{tabular}{|c|c|c|c|c|c|c|c|}
\hline 1 & PG & & & & $\mathrm{M}-\mathrm{L}+\mathrm{VG}$ & $M-L+V G$ & $M-L+V G$ \\
\hline 2 & $P G$ & TG1 & TG2 & TG3 & M-L+VG & $M-L+V G$ & $\mathrm{M}-\mathrm{V}$ \\
\hline 3a & PG & TG1 & TG2 & TG3 & JvB & $M-L+V G$ & $M-\mathrm{V}$ \\
\hline $3 \mathbf{b}$ & PG & TG1 & TG2 & TG3 & ]$V B+V G$ & $M-L+V G$ & $\mathrm{M}-\mathrm{V}$ \\
\hline 4 & PG & TG1 & TG2 & TG3 & $\mathrm{M}-\mathrm{L}+\mathrm{VG}$ & $M-V$ & TR \\
\hline 5 & PG & TG1 & TG2 & TG3 & VB & $M-L$ & TR \\
\hline 6 & PG & TG1 & TG2 & TG3 & VB & $M-L$ & VBo \\
\hline 7 & PG & TG1 & TG2 & TG3 & VB & $M-L$ & VBO+GR \\
\hline 8 & PG & LU1 & LU2 & LU3 & VB & $M-L$ & TR \\
\hline 9 & PG & LU1 & LU2 & LU3 & VB & $M-L$ & VBO \\
\hline 10 & $P G$ & $\mathrm{TG}+\mathrm{R}$ & TG+RK2 & $T G+R K 3$ & $\mathrm{M}-\mathrm{L}+\mathrm{VG}$ & $M-L+V G$ & $M-\mathrm{V}$ \\
\hline 11 & PG & $T G+R$ & TG+RK2 & $T G+R K 3$ & $M-L+V G$ & $M-L+V G$ & VBO \\
\hline
\end{tabular}

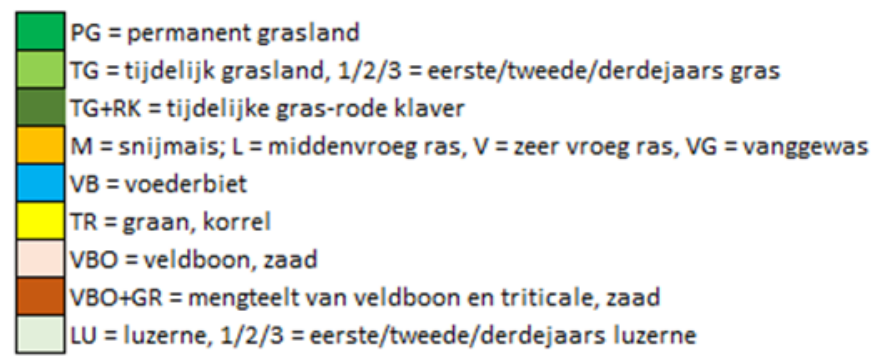

Figuur 1 Beschouwde bouwplannen op een melkveebedrijf met $80 \%$ grasland en 20\% bouwland.

\subsubsection{Uitgangspunten en berekeningen}

\subsubsection{Aanvoer Effectieve Organische Stof}

De organische stof huishouding van de bouwplannen is beoordeeld op basis van de aangevoerde hoeveelheid effectieve organische stof (EOS) uit gewasresten en dierlijke mest. De EOS is de organische stof die een jaar na toediening nog aanwezig is en een bijdrage levert aan de humusopbouw in de bodem. Er is uitgegaan van de EOS-kengetallen (dierlijke mest, groenbemesters en gewasresten) zoals weergegeven in het Handboek Bodem en Bemesting (Anonymus, 2019d).

\subsubsection{Droge stof, eiwit en energie opbrengst}

In tabel 3 zijn de gehanteerde kengetallen voor opbrengst en kwaliteit weergegeven waarmee de totale droge stof (DS) opbrengst, totale ruw eiwit (RE) opbrengst, totale opbrengst darmverteerbaarheid eiwit (DVE) en totale opbrengst voedereenheid melk (VEM) van de bouwplannen is berekend. Alle opbrengsten betreffen de producten zoals die vervoederd worden; vers gras, graskuil, luzernekuil, gras-rode klaver kuil, maïskuil, verse voederbieten, triticale korrel en de boon van de veldboon. Doorgaans worden opbrengsten van graan en peulvruchten gegeven bij een 
standaardvochtgehalte, deze zijn omgerekend naar droge stof. Voor de voederwaarde is zo veel mogelijk uitgegaan van de gegevens van het Centraal Veevoeder Bureau (Anonymus, 2018), tenzij anders vermeld. Ook de voederwaarde heeft betrekking op de producten zoals ze vervoederd worden.

\section{Permanent en tijdelijk grasland}

Bij het gewas "permanent en tijdelijk grasland" (Tabel 3) is ervan uitgegaan dat zowel op het permanente grasland als het tijdelijke grasland wordt geweid en gemaaid (gecombineerd graslandgebruik). Daarom wordt er zowel graskuil als weidegras gewonnen.

De grasopbrengst van "permanent en tijdelijk grasland" is gesteld op 8,7 ton ds/ha uitgaande van een bruto grasopbrengst van 10,8 ton ds/ha voor gecombineerd gebruik inclusief $20 \%$ verliezen (Schils et al, 2018). Ervan uitgaande dat $2 / 3$ deel wordt gewonnen als kuilgras en $1 / 3$ deel als weidegras worden de droge stofopbrengst kuilgras en weidegras respectievelijk, 5,8 ton ds/ha, en 2,9 ton ds/ha (Tabel 3). Er is geen onderscheid gemaakt in jaarproductie tussen permanent en tijdelijk grasland.

De voederwaarde voor "permanent en tijdelijk grasland" is een gewogen gemiddelde berekend op basis van voederwaarde voor weidegras en graskuil (Anonymus, 2018) naar het aandeel in de totale droge stofopbrengst (Tabel 3).

In bouwplan 1 tot en met 9 wordt gebruik gemaakt van het gewas "permanent en tijdelijk grasland".

\section{Permanent grasland en gras-rode klaver}

Bij het gewas "permanent grasland en gras-rode klaver" (tabel 3) wordt er naast gras ook gras-rode klaver verbouwd in de graslandfase. Op het permanente grasland wordt zowel gemaaid als geweid (gecombineerd graslandgebruik). De gras-rode klaver wordt alleen gemaaid.

De opbrengst van "permanent grasland en gras-rode klaver" is een combinatie van de opbrengst van weidegras, graskuil en gras-rode klaver kuil. Waarbij de verhouding weidegras, graskuil en gras-rode klaver is bepaald door het aandeel permanent grasland (75\% van het areaal grasland) en gras-rode klaver (25\% van het areaal grasland) in het bouwplan.

De grasopbrengst van het permanente grasland is gesteld op 8.7 ton ds/ha uitgaande van een bruto grasopbrengst van 10.8 ton ds/ha voor gecombineerd gebruik inclusief $20 \%$ verliezen (Schils et al, 2018). Ervan uitgaande dat $2 / 3$ deel wordt gewonnen als kuilgras en $1 / 3$ deel als weidegras wordt de droge stofopbrengst aan kuil- en weidegras respectievelijk, 5.8 ton ds/ha, en 2.9 ton ds/ha (tabel 3).

Bij gras-rode klaver is ervan uitgegaan dat dit gewas uitsluitend wordt gemaaid en ingekuild. De gewasopbrengst is gesteld op 10.8 ton ds/ha uitgaande van een bruto gewasopbrengst van 13.5 ton droge stof/ha (Van Eekeren et al., 2009) inclusief 20\% verliezen (tabel 3).

De voederwaarde voor "permanent grasland en gras-rode klaver" is een gewogen gemiddelde berekend op basis van voederwaarde voor weidegras, graskuil en gras-rode klaver kuil (Anonymus, 2018) naar het aandeel in de totale droge stofopbrengst (tabel 3).

In bouwplan 10 en 11 wordt gebruik gemaakt van het gewas "permanent grasland en gras-rode klaver".

\section{Overige gewassen}

Voor de snijmais is in de referentiesituatie uitgegaan van een opbrengstniveau van 16 ton drogestof per ha bij een oogst rond eind september. Bij de mais die in vruchtwisseling wordt geteeld wordt een $10 \%$ hogere opbrengst aangehouden (De Wolf et al., 2017). In het jaar voorafgaand aan de gras- of luzerneperiode wordt een vroeger ras gezaaid, zodat rond half september het gras of de luzerne kan worden ingezaaid. Hiervoor is een lagere opbrengst ingerekend. Wanneer de mais wordt gevolgd door triticale en winterveldboon is uitgegaan van een normaal oogsttijdstip (eind september).

Zoals eerder aangegeven is bij voederbieten onderscheid gemaakt tussen een vroege en late oogst. $\mathrm{Bij}$ een late oogst is uitgegaan van een gemiddelde veldopbrengst van 18 ton drogestof per ha (Latré et al, 2018). Vervolgens heeft nog een correctie plaatsgevonden voor bewaarverliezen. 
Bij de vroege oogst is uitgegaan van een oogst eind september, zodat de bieten tegelijk met de mais kunnen worden in gekuild. Hierbij is uitgegaan van een $7 \%$ lagere veldopbrengst en een conserveringsverlies van $10 \%$.

De triticale-opbrengst is gebaseerd op een gemiddelde wintertarweopbrengst op zandgrond van circa 8 ton per ha bij een standaardvochtgehalte van $14 \%$, die vervolgens is omgerekend naar een drogestofopbrengst.

De opbrengsten en voederwaarde van winterveldboon en een mengteelt van winterveldboon en triticale zijn gebaseerd op Prins \& Van Krimpen (2007).

Bij luzerne is uitgegaan van een veldjaaropbrengst van 12.5 ton drogestof per ha (Van der Schans, 1998). Deze is vervolgens omgerekend naar een kuilopbrengst via een correctie voor veld- en conserveringsverliezen.

\subsubsection{Melkproductie uit eigen voer en aan te kopen voer}

Om inzicht te geven in de potentie van de bouwplannen voor de melkproductie is voor bouwplan 1 tot en met 11 berekend hoeveel melk er geproduceerd kan worden, welk aandeel van de melkproductie uit eigen voer wordt geproduceerd, hoeveel voer er aangekocht moet worden en wat de samenstelling van dat voer moet zijn om aan de behoefte van de melkkoeien te voldoen.

Hierbij is ervan uitgegaan dat al het eigen voer ter beschikking komt van de melkkoeien. De voederbehoefte is berekend voor de gemiddelde Nederlandse koe in 2018 gebaseerd op gegevens van het Centraal Bureau voor de Statistiek Tabel 4, Anonymus (2019)).

Met deze gegevens is de VEM behoefte van de gemiddelde Nederlandse koe berekend volgens de systematiek van de Werkgroep Uniformering Mestcijfers (Schröder et al. 2019) en de DVE behoefte van de gemiddelde Nederlandse koe op basis van de CVB normen (Anonymus 2016a) (Tabel 5). Bijlage 3 geeft informatie over de gebruikte verzadigingswaarde (Tabel B3a) en de opbouw van de energie- (Tabel B3b) en eiwitbehoefte (Tabel B3c) van de gemiddelde Nederlandse koe.

Vervolgens is op basis van het Koemodel (Zom, 2014) voor de gemiddelde Nederlandse koe een gewogen voeropnamecapaciteit (VOC) per jaar bepaald.

Tevens is op basis van de verzadigingswaarde van elk voedermiddel een gemiddelde verzadigingswaarde voor elk bouwplan vastgesteld (Anonymus (2018), (Anonymus 2016a)). Door middel van lineaire optimalisatie, met als beperkende randvoorwaarden dat de VEM dekking $100 \%$ moet zijn, en dat de opname van verzadigingswaarde eenheden gelijk is aan de voeropname capaciteit, is voor elk bouwplan berekend hoeveel aangekocht voer op jaarbasis nodig is om aan de VEM behoefte van de gemiddelde Nederlandse koe te voldoen. Vervolgens is voor elk bouwplan het minimaal DVE gehalte per $\mathrm{kg}$ aangekocht voer berekend om aan de DVE behoefte van de gemiddelde Nederlandse koe te voldoen. Bovendien is de Onbestendig Eiwit Balans (OEB) van het aangekochte voer berekend om aan te geven hoe het voer moet bijdragen aan de OEB balans. Hierbij is ervan uitgegaan dat het aangekochte voer bestaat uit één product. Tabel 6 geeft de overige specificaties van het aangekochte voer.

Met behulp van de DVE opname met de droge stof (DVE/koe/jaar) en de totale DVE opbrengst van een bouwplan is vervolgens berekend hoeveel melkkoeien er gevoerd kunnen worden. Met het aantal koeien dat gevoed kan worden en de melkproductie $(\mathrm{kg} / \mathrm{koe} / \mathrm{jaar}$; tabel 4$)$ is vervolgens de totale melkproductie van elk bouwplan berekend.

Met de verhouding DVE uit aangekocht voer en DVE uit eigen voer is berekend welk aandeel van de melkproductie uit eigen voer is geproduceerd en welk aandeel uit aanvullend voer.

Om dit te vertalen naar handelingsperspectieven is berekend hoeveel DVE aangekocht moet worden en wat de gehalten aan DVE en OEB in de droge stof van het aangekochte voer moet zijn. 
Tabel 3 Gehanteerde waarden voor opbrengst en kwaliteit (energie: VEM; eiwit: ruw eiwit (RE) en darmverteerbaar eiwit (DVE); verzadigings waarde eenheden (VW); onbestendig eiwitbalans (OEB). Het betreft de opbrengst en voederwaarde van de te vervoederen producten.

\begin{tabular}{|c|c|c|c|c|c|c|}
\hline Gewas & $\begin{array}{l}\text { Droge } \\
\text { stofopbrengst } \\
\text { producten } \\
\text { (kg ds/ha) }\end{array}$ & VEM/kg ds & $\mathrm{g} \mathrm{RE} / \mathrm{kg}$ ds & $\mathrm{g}$ DVE/kg ds & $\mathrm{VW} / \mathrm{kg}$ ds & $\mathrm{g} \mathrm{OEB} / \mathrm{kg} \mathrm{ds}$ \\
\hline $\begin{array}{l}\text { Permanent en tijdelijk } \\
\text { grasland } \\
\text { samengesteld uit }{ }_{1}\end{array}$ & 8.7 & 946 & 173 & 73 & & \\
\hline Gras, kuil & 5.8 & 929 & 158 & 63 & 1.04 & 63 \\
\hline Gras, weide & 2.9 & 981 & 204 & 92 & 0.91 & 18 \\
\hline $\begin{array}{l}\text { Permanent grasland } \\
\text { en tijdelijk gras-rode } \\
\text { klaver samengesteld } \\
\text { uit2 }\end{array}$ & 8.9 & 894 & 172 & 69 & & \\
\hline Gras, kuil & 5.8 & 929 & 158 & 63 & 1.04 & 63 \\
\hline Gras, weide & 2.9 & 981 & 204 & 92 & 0.91 & 18 \\
\hline $\begin{array}{l}\text { Gras-rode klaver, } \\
\text { kuil }\end{array}$ & 10.8 & 718 & 153 & 47 & 0.96 & 61 \\
\hline Snijmais, kuil, vroeg & 16.0 & 980 & 75 & 52 & 0.83 & -40 \\
\hline $\begin{array}{l}\text { Snijmais, kuil, laat, } \\
\text { continu }\end{array}$ & 16.0 & 980 & 75 & 52 & 0.83 & -40 \\
\hline $\begin{array}{l}\text { Snijmaïs, kuil, laat, } \\
\text { vruchtwisseling }\end{array}$ & 17.6 & 980 & 75 & 52 & 0.83 & -40 \\
\hline Voederbiet, laat3 & 17.3 & 1056 & 78 & 101 & 0.69 & -92 \\
\hline 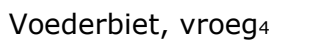 & 15.1 & 1056 & 78 & 101 & 0.69 & -92 \\
\hline Triticale, korrels & 6.7 & 1035 & 107 & 99 & 0.25 & -47 \\
\hline Veldboon, zaad6 & 5.2 & 1037 & 276 & 107 & 0.3 & 123 \\
\hline $\begin{array}{l}\text { Veldboon+triticale } \\
(\text { korrel }+ \text { zaad })_{7}\end{array}$ & 6.7 & 1040 & 187 & 97 & 0.30 & 46 \\
\hline Luzerne, kuils & 10.9 & 678 & 184 & 38 & 0.96 & 99 \\
\hline
\end{tabular}

1 Gecombineerd graslandgebruik: 2/3 van grasopbrengst wordt geoogst als graskuil en 1/3 als weidegras.

$225 \%$ van graslandareaal bestaat uit gras-rode klaver, $75 \%$ graslandareaal is permanent grasland met gecombineerd gebruik waarvan $2 / 3$ wordt geoogst als kuilgras en 1.3 als weidegras.

3 Veldopbrengst van 18 ton ds per ha en 4\% bewaarverlies, voederwaarde CVB 2018

4 Opbrengstverlies van $300 \mathrm{~kg}$ ds/week a.g.v. 4 weken eerdere oogst t.o.v. standaard oogst; $10 \%$ kuilverlies

5 Korrelopbrengst van 8 ton per ha met 16\% vocht, voederwaarde CVB 2018

6 Korrelopbrengst van 6 ton per ha met $16 \%$ vocht, voederwaarde uit Prins \& Van Krimpen (2007)

7 Korrelopbrengst van 8 ton per ha met $16 \%$ vocht, voederwaarde uit Prins \& Van Krimpen (2007)

8 Veldproductie van 12.5 ton ds per ha, 4\% veldverliezen en 9\% inkuilverliezen, voederwaarde CVB, 2018 
Tabel 4 Kenmerken gemiddelde Nederlandse koe (CBS, 2019)

\begin{tabular}{lll}
\hline Melkgift & 8674 & $\mathrm{~kg} / \mathrm{jaar}$ \\
Vet & 4.39 & $\%$ \\
Eiwit & 3.57 & $\%$ \\
Gewicht & 650 & $\mathrm{~kg}$ \\
Tussen kalf tijd & 420 & dagen \\
Dagen lactatie/jaar & 315 & dagen \\
Dagen droogstand & 55 & dagen \\
Vervanging\% & 28 & $\%$ \\
Kalveren/koe & 0.7 & \\
\hline
\end{tabular}

Tabel 5 Behoefte aan energie, eiwit en de verhouding energie-verzadigingswaarde van de gemiddelde Nederlandse koe

\begin{tabular}{lll}
\hline Kenmerk & Benodigde waarde & Eenheid \\
\hline Energie & 6715 & $\mathrm{kVEM} / \mathrm{koe} / \mathrm{jaar}$ \\
Eiwit & 555 & $\mathrm{~kg} \mathrm{DVE/koe/jaar}$ \\
VEM/VW & 1211 & \\
\hline
\end{tabular}

$\mathrm{VEM}=$ voedereenheid melk, DVE = darm verteerbaar eiwit, $\mathrm{VW}=$ verzadigingswaarde

Tabel 6 Samenstelling gekocht krachtvoer

\begin{tabular}{lccc}
\hline & DS\% & VW/kg ds & VEM/kg ds \\
\hline Gekocht krachtvoer & 88.8 & 0.28 & 960 \\
\hline
\end{tabular}

$\mathrm{VEM}=$ voedereenheid melk, $\mathrm{VW}=$ verzadigingswaarde, $\mathrm{DS}=$ droge stof 


\section{Resultaten}

\subsection{Continuteelt mais met wintergewas}

\subsubsection{Aanvoer effectieve organische stof}

In de systemen met meer ruimte voor wintergewassen (Inwerk1, Inwerk2, Oogst1 en Oogst2) wordt meer EOS aangevoerd (Figuur 2) dan in de referentiesituatie met een later maisras. Bij oogsten van het wintergewas is de EOS-aanvoer wat lager dan bij inwerken. Hoewel de verschillen niet groot zijn, kan dat wel het verschil zijn tussen het wel of niet op peil kunnen houden van het organische stofgehalte in de bodem.

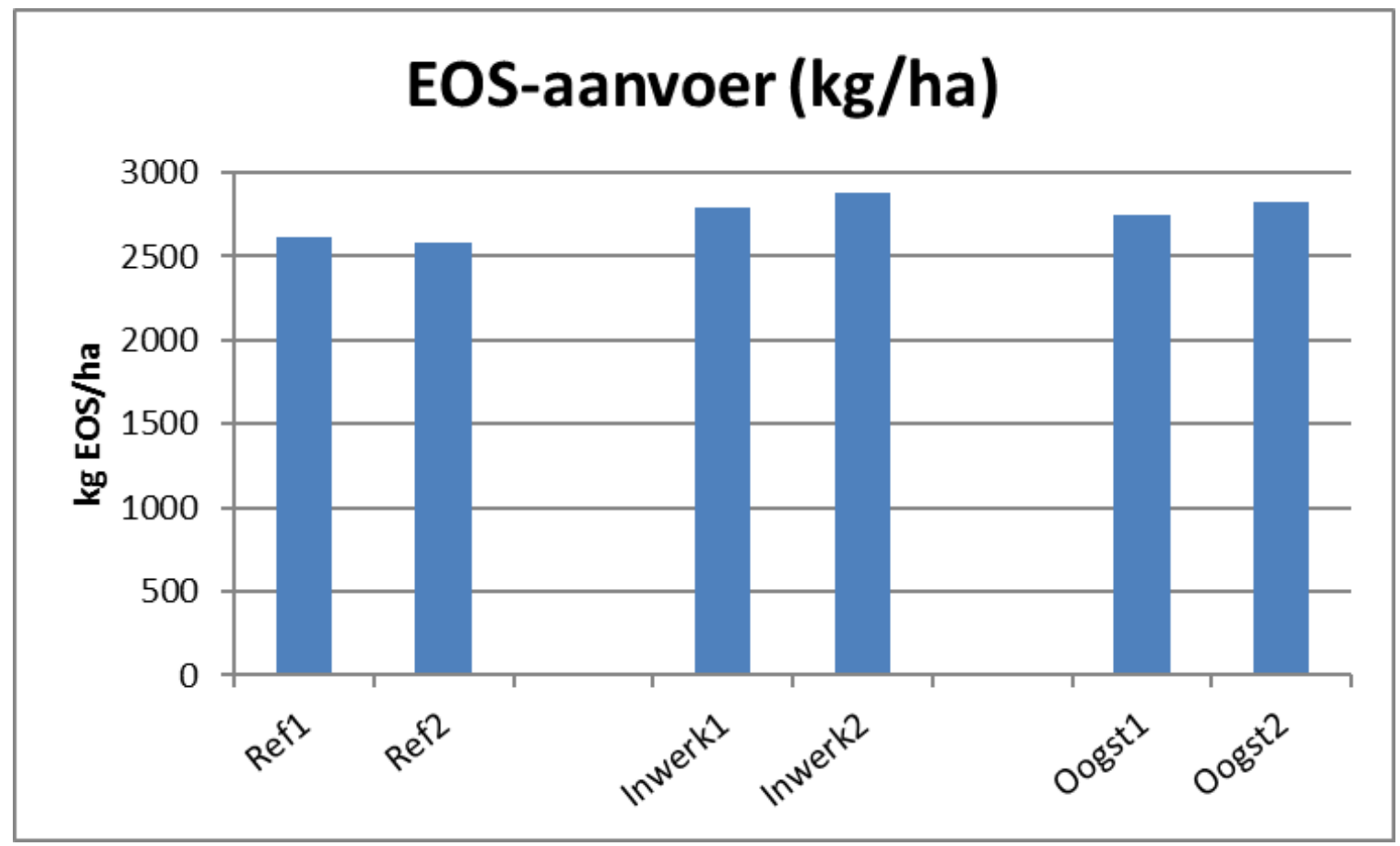

Figuur 2 Aanvoer van effectieve organische stof (EOS) uit gewasresten (inclusief wintergewas) en dierlijke mest (35 m3 rundveedrijfmest per ha) bij de vergeleken teeltsystemen (voor beschrijving varianten zie paragraaf 2.1 ).

\subsubsection{Financiële effecten}

In Figuur 3 zijn de financiële effecten weergegeven. Bij de referentievarianten (Ref1 en Ref2) is het saldo bij grasonderzaai wat hoger dan bij rogge. Dit komt door de hogere maisopbrengst bij grasonderzaai, doordat minder vroeg hoeft te worden geoogst. Bij de teeltkosten zijn er vrijwel geen verschillen. Weliswaar zijn de kosten voor zaaizaad en zaaien wat hoger bij grasonderzaai, maar dit wordt grotendeels gecompenseerd doordat er na de oogst geen stoppelbewerking nodig is.

Het telen van een vroeger maisras in combinatie met een geoogst tussengewas (Oogst1 en Oogst2) geeft een lager financieel saldo dan de referentievarianten. Dit is ook het geval als de totale drogestofopbrengst (mais + tussengewas) vergelijkbaar is met de referentievariant (vergelijk Ref1 en Oogst1). Dit komt door de lagere voederwaarde van het tussengewas t.o.v. van de mais en de hogere oogstkosten. Er moeten nu twee gewassen worden geoogst voor eenzelfde droge stofproductie. Economisch lijkt het interessanter te kiezen voor het inwerken, het saldo is slechts $€ 20-€ 50$ per ha lager dan bij de referentievarianten. Bij onderzaai van gras pakt dat wat gunstiger uit dan bij nazaai van rogge doordat ervan uitgegaan is dat voor eenzelfde biomassaproductie van het tussengewas de 


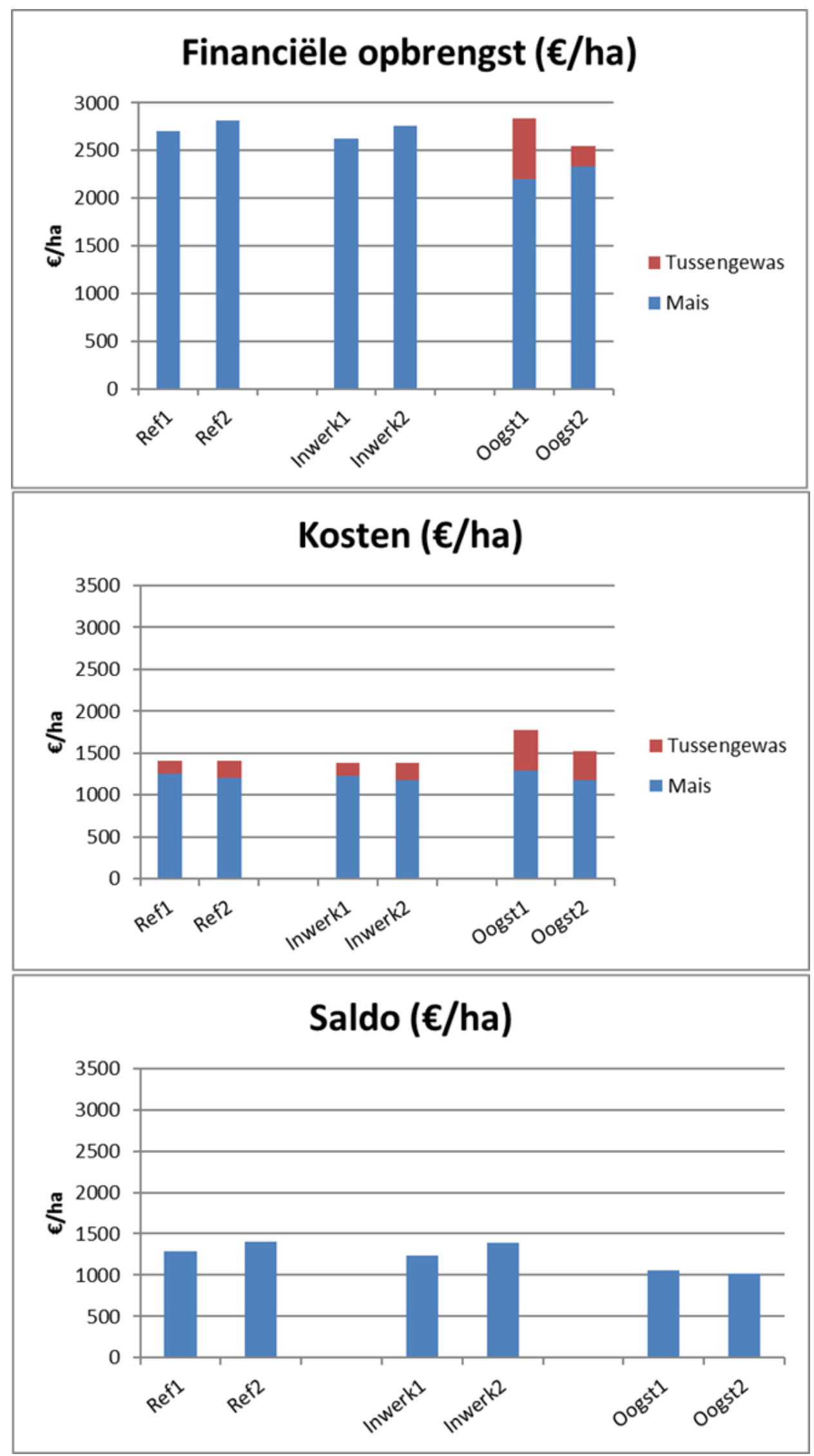

Figuur 3 Financiële opbrengst, teeltkosten en saldo (mais + tussengewas, alle in $€ / h a$ ) van de vergeleken teeltsystemen (voor beschrijving varianten zie paragraaf 2.1 ). 


\subsection{Vruchtwisseling met andere gewassen}

\subsubsection{Aanvoer effectieve organische stof}

In Figuur 4 is de EOS-aanvoer weergegeven bij de verschillende bouwplannen. In de bovenste figuur is de totale aanvoer op bedrijfsniveau weergegeven en in de onderste figuur de aanvoer op het permanente grasland, het permanente bouwland (alleen bouwplan 1) en het wisselbouwdeel in de verschillende bouwplannen. Dit onderscheid is gemaakt, omdat er in de bouwplannen sprake is van meerdere rotaties. Zo is er in bouwplan 1 een deel permanent grasland ( $80 \%)$ en een deel permanent bouwland (20\%). In alle andere bouwplannen is er een deel permanent grasland $(60 \%)$ en een deel wisselbouw (40\%). Omdat deze rotaties binnen een bouwplan los van elkaar staan moeten deze ook apart worden beoordeeld wat betreft organische stofaanvoer. De totale aanvoer van het bouwplan (bovenste figuur) zegt agronomisch minder, maar geeft wel een indicatie over de effecten van het totale bouwplan op de totale koolstofaanvoer.

Omdat er geen specifieke kengetallen beschikbaar zijn voor gras + rode klaver, zijn de bouwplannen met rode klaver niet weergegeven in de figuren.

De verschillen in totale EOS-aanvoer tussen de bouwplannen zijn gering (Figuur 4, boven). In vergelijking met de situatie zonder vruchtwisseling (bouwplan 1) neemt de EOS-aanvoer licht toe in de vruchtwisselingsvarianten. De aanvoer is het hoogst in de rotaties met graan (bouwplan 4 en 5 ). Bij de bouwplannen waarin het tijdelijk grasland is vervangen door luzerne is de EOS-aanvoer het laagst. Dit komt door de lagere EOS-aanvoer van luzerne in vergelijking met grasland. Benadrukt moet worden dat een verschil in EOS-aanvoer niet perse betekent dat er verschillen zijn in koolstofvastlegging van het bouwplan. Dit hangt mede af van de jaarlijkse afbraak. Hieraan zijn in deze studie geen berekeningen uitgevoerd.

De relatief geringe verschillen in EOS-aanvoer tussen de bouwplannen zijn een gevolg van het hoge aandeel gras ( $80 \%$ in de meeste rotaties) dat een hoge aanvoer van EOS geeft op gewasniveau. Hierdoor hebben veranderingen in het bouwlanddeel, dat een relatief laag aandeel uitmaakt van het bedrijf $(20 \%)$, relatief geringe effecten. Daarnaast speelt mee dat de verschillen in EOS-aanvoer tussen de bouwlandgewassen niet groot zijn uiteenlopend van $1000 \mathrm{~kg}$ EOS per ha voor snijmais + groenbemester tot ruim $1500 \mathrm{~kg}$ EOS per ha voor triticale (waarbij het stro is afgevoerd).

Hoewel de totale EOS-aanvoer weinig verschilt tussen de bouwplannen, verbetert bij wisselbouw met gras wel de situatie voor het bouwland (Figuur 4, onder). De totale EOS-aanvoer voor het wisselbouwdeel van het bedrijf (bouwplannen $2 \mathrm{t} / \mathrm{m}$ 9) is hoger dan bij de continuteelt van mais (bouwplan 1 , PB). 


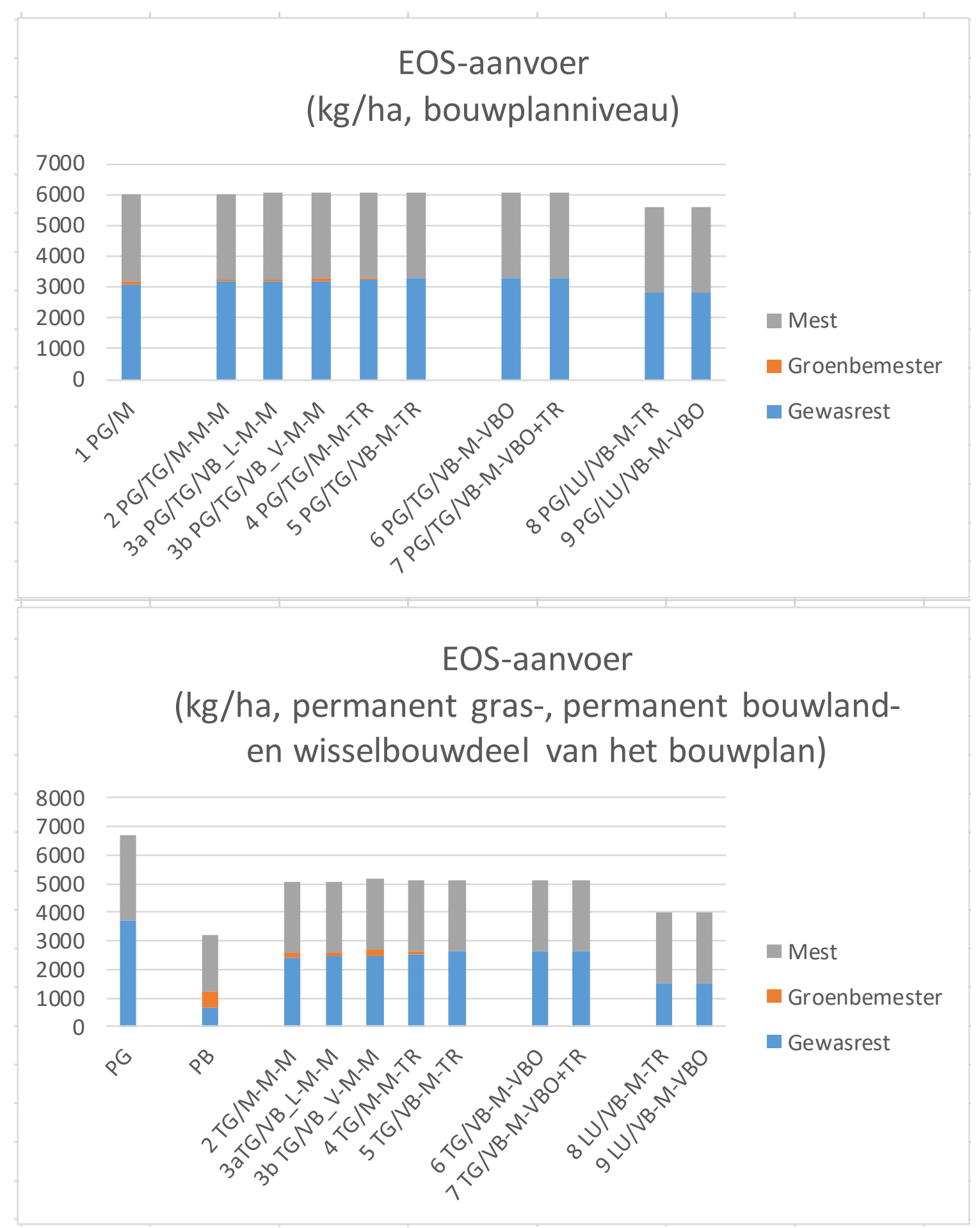

Figur 4 Aanvoer van effectieve organische stof (EOS) via dierlijke mest, groenbemesters en gewasresten op bouwplanniveau (boven) en de aanvoer bij permanent grasland (alle bouwplannen), permanent bouwland ( $P B$, continue mais, bouwplan 1) en bij het wisselbouwdeel (alle bouwplannen m.u.v. bouwplan 1) bij de verschillende bouwplannen (onder) ( $P G=$ permanent grasland, $P B=$ permanent bouwland, $T G=$ tijdelijk grasland, $M=$ mais, $V B \_L=$ laat geoogste voederbiet, $V B \_V=$ vroeg geoogste voederbiet, $T R=$ triticale, $V B O=$ veldboon, $L U=$ luzerne) 


\subsubsection{Voederwaarde opbrengst}

Wisselbouw van mais en gras (bouwplan 2) geeft t.o.v. volledig blijvend grasland en continue mais (bouwplan 1) een hogere VEM, RE en DVE opbrengst als gevolg van de hogere maisopbrengst bij wisselbouw (Figuur 5).

Het bouwplan waarin een jaar mais vervangen is door laat geoogste voederbieten (vergelijk bouwplan 2 met 3a) geeft een hogere VEM- en eiwitopbrengst als gevolg van de hogere VEM- en eiwitopbrengst van de voederbieten in vergelijking met mais. Vervanging van een jaar mais door triticale (vergelijk bouwplan 2 en 4 ) of veldbonen (vergelijk bouwplan 3a met 6/7 of vergelijk bouwplan 10 met 11) verlaagt de VEM-productie door de lagere VEM-opbrengst van de gewassen die de mais deels vervangen. De RE-opbrengst is echter wel hoger als mais deels wordt vervangen door veldbonen.

De bouwplannen waarin het tijdelijk grasland is vervangen door luzerne (bouwplan 8 en 9) geven de hoogste ruw eiwitopbrengst. Dit komt vooral door hogere opbrengst van luzerne in vergelijking met gras en door een wat hoger ruw eiwitgehalte. De VEM-opbrengst is bij luzerne lager door de lagere VEM-waarde. Dit wordt onvoldoende gecompenseerd door de hogere luzerne-opbrengst. Het vervangen van tijdelijk gras door tijdelijk gras-klaver in het wisselbouwsysteem (vergelijk bouwplan 2 met 10) geeft een lagere VEM-opbrengst. De hogere droge stofopbrengst van gras-klaver t.o.v. gras wordt teniet gedaan door de lagere VEM-waarde van gras-klaver. De ruw eiwitopbrengst is bij gras-klaver wel wat hoger dan bij alleen gras.

In aanvulling op Figuur 5 geeft Figuur 6 de RE- en DVE-opbrengst van de bouwplannen in één grafiek. Figuur 6 laat zien dat de bouwplannen met een hoge RE opbrengst/ha (bouwplan 8, 9, 10 en 11) niet automatisch een hoge DVE opbrengst/ha hebben. Terwijl de bouwplannen $3 a, 3 b, 5,6$ en 7 juist een hogere DVE opbrengst hebben dan op basis van de RE opbrengst wordt verwacht.

Figuur 5 laat zien dat dit komt door de bijdrage van voederbiet in bouwplan 3a, 3b, 5, 6 en 7; voederbiet heeft een relatief hoog DVE gehalte (Tabel 3). In bouwplan 8 en 9 kan de DVE opbrengst uit voederbiet de lagere DVE opbrengst aan luzernekuil niet compenseren. In bouwplan 11 wordt de lagere DVE opbrengst veroorzaakt door de DVE opbrengst uit veldboon. Zie Bijlage 1 - figuurB1a voor de DVE/RE verhouding voor de individuele voedermiddelen. 


\section{kVEM/ha}
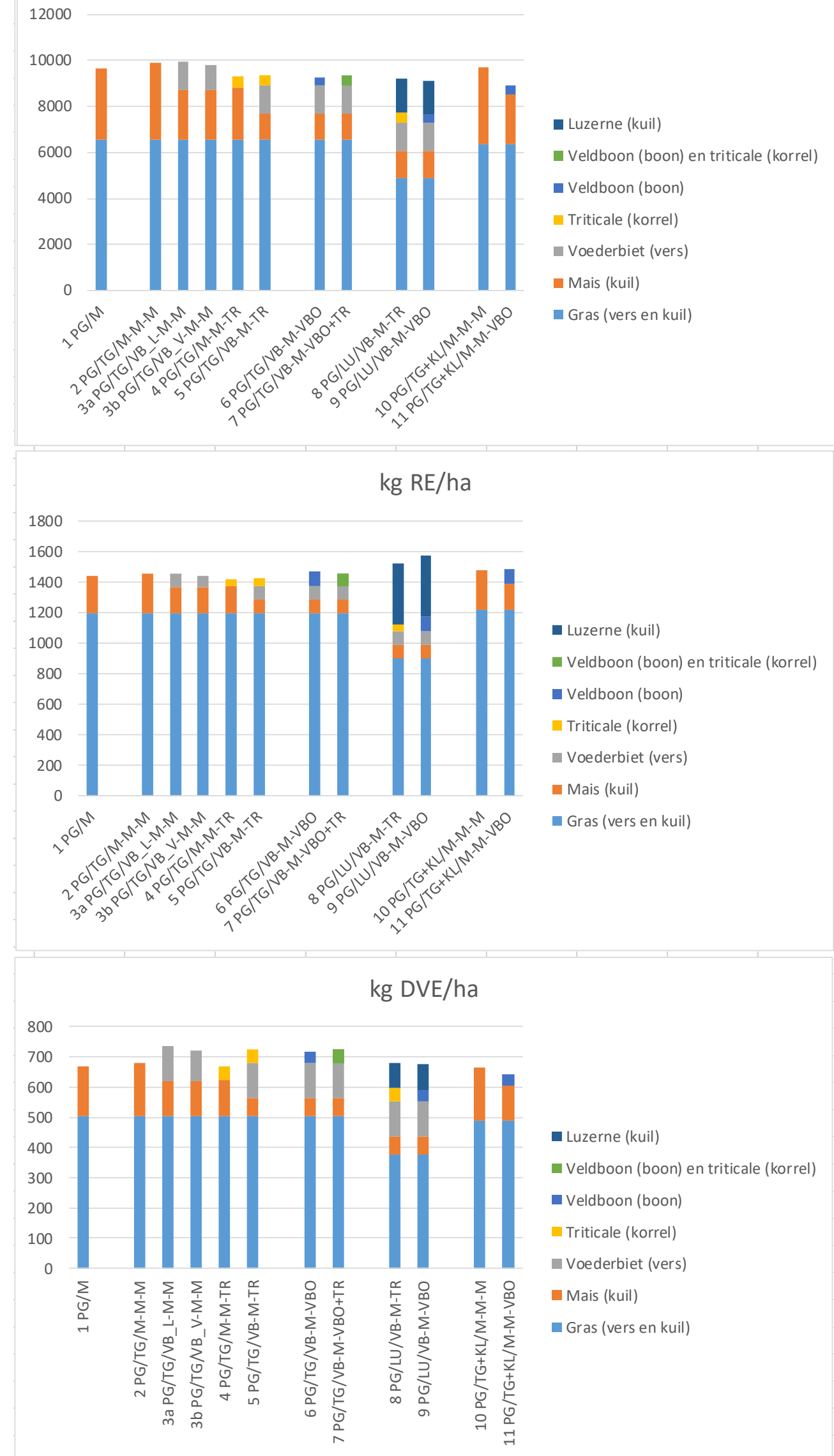

Figuur $5 \quad$ Opbrengst voedereenheid melk (VEM), ruw eiwit (RE) en darm verteerbaar eiwit (DVE) in $\mathrm{kg} /$ ha voor bouwplan $1 \mathrm{t} / \mathrm{m}$ bouwplan 11 uitgesplitst naar voedermiddel ( $P G=$ permanent grasland, $T G=$ tijdelijk grasland, $T G+K L=$ tijdelijk gras + rode $k l a v e r, M=$ mais, $V B \_L=$ laat geoogste voederbiet, $V B \_V=$ vroeg geoogste voederbiet, $T R=$ triticale, $V B O=$ veldboon, $L U=$ luzerne). 


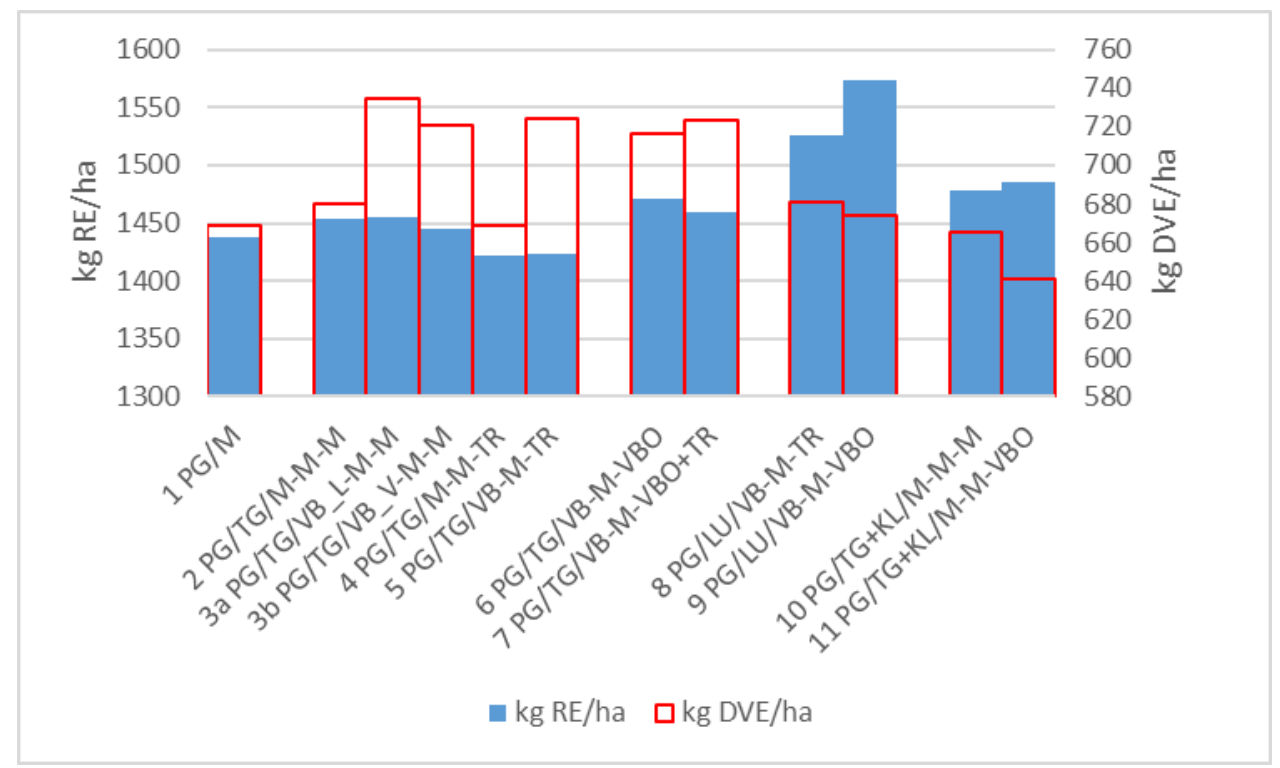

Figuur 6 Opbrengst ruw eiwit (RE) en darm verteerbaar eiwit (DVE) in kg/ha voor bouwplan $1 \mathrm{t} / \mathrm{m}$ bouwplan 11 ( $P G=$ permanent grasland, $T G=$ tijdelijk grasland, $T G+K L=$ tijdelijk gras + rode klaver, $M=$ mais, $V B \_L=$ laat geoogste voederbiet, $V B \_V=$ vroeg geoogste voederbiet, $T R=$ triticale, $V B O=$ veldboon, $L U=$ luzerne).

\subsubsection{Melkproductie uit eigen voer}

Figuur 7 laat zien dat onder de voorwaarden van deze studie, (melkproductie gemiddelde Nederlandse koe van $8674 \mathrm{~kg} / \mathrm{koe} / \mathrm{jaar}$ met $4.39 \%$ vet en $3.57 \%$ eiwit, en het feit dat al het eigen voer wordt gebruikt voor de melkkoeien) de totale melkopbrengst verschilt voor de bouwplannen, maar ook dat het aandeel melk dat geproduceerd wordt uit eigen voer verschilt tussen de bouwplannen.

In het bouwplan met gras en mais in continuteelt (bouwplan 1) is de melkproductie 975 ton per jaar en wordt $64 \%$ van deze melk geproduceerd uit eigen voer. Wanneer de maïs in vruchtwisseling wordt verbouwd (bouwplan 2) is de melkproductie 16 ton hoger (991 ton per jaar) en wordt ook 64\% van de melk geproduceerd uit eigen voer.

In bouwplan 10, waar het aandeel tijdelijk grasland is vervangen door gras rode klaver, is de melkproductie het hoogst van alle varianten (1080 ton per jaar). Echter het aandeel melk dat uit eigen voer wordt geproduceerd is met $58 \%$ het laagst. De bouwplannen met de laagste melkproductie van 878 ton jaar (bouwplan 5, bouwplan 6 en bouwplan 7), produceren $77 \%$ hiervan uit eigen voer. Vervanging van een deel van de mais door voederbieten en/of triticale (vergelijk bouwplan 3/4/5 met bouwplan 2) leidt tot een lagere totale melkproductie. Wel is bij vervanging van mais door voederbiet het aandeel melkproductie van eigen geteeld voer hoger.

Vervanging van een deel van de mais door veldbonen of een mix van triticale een veldbonen (vergelijk bouwplan 6/7 met bouwplan 2) geeft de laagste totale melkproductie. 


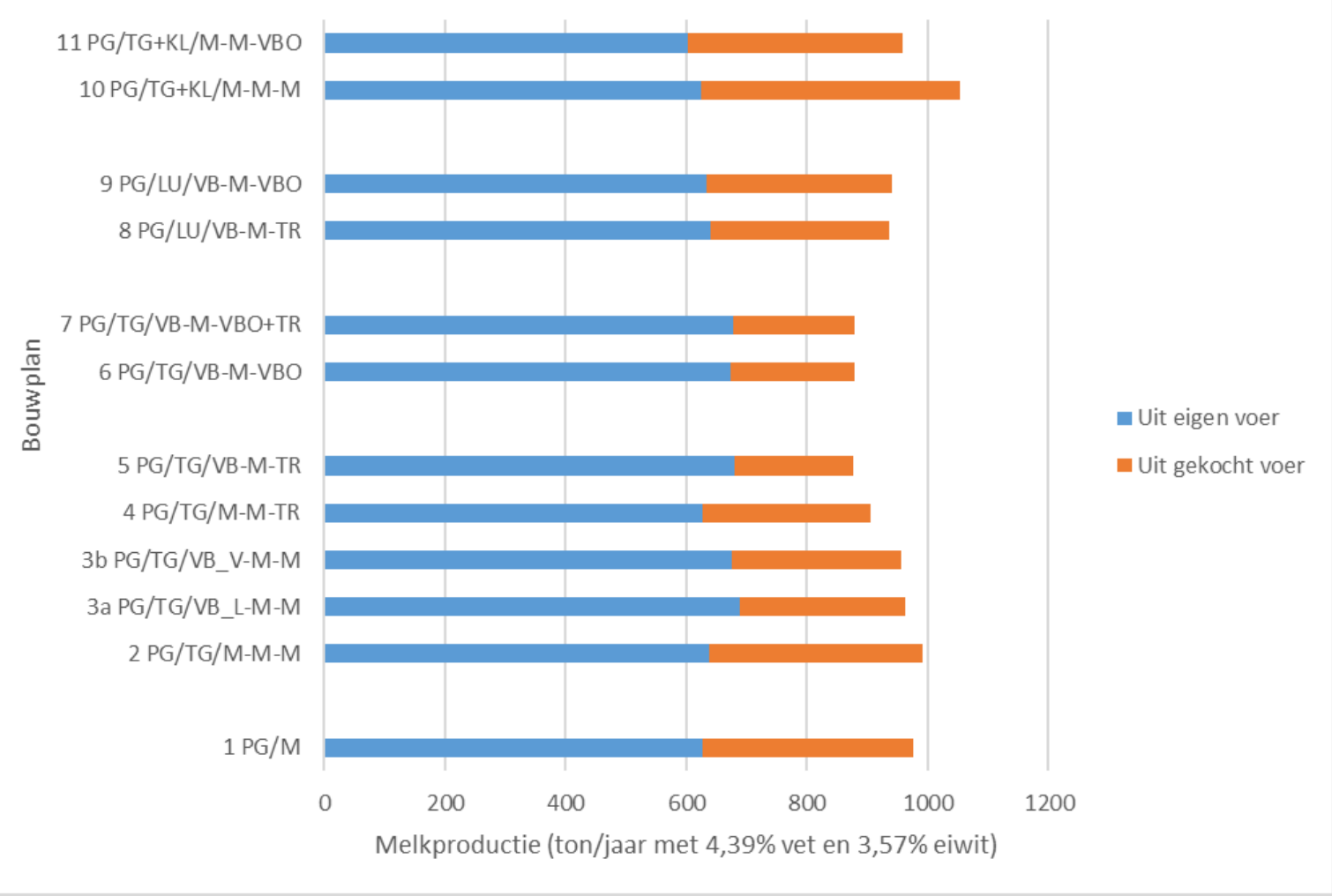

Figuur 7 Melkproductie (x $1000 \mathrm{~kg} / \mathrm{jaar}$ ) bouwplan $1 \mathrm{t} / \mathrm{m}$ bouwplan 11 gespecificeerd naar eigen en gekocht voer $(P G=$ permanent grasland, $T G=$ tijdelijk grasland, $T G+K L=$ tijdelijk gras + rode klaver, $M=$ mais, VB_L = laat geoogste voederbiet, $V B \_V=$ vroeg geoogste voederbiet, $T R=$ triticale, $V B O=$ veldboon, $L U=$ luzerne)

\section{Aantal te houden koeien}

Omdat we in deze studie ervan uitgaan dat al het eigen voer aan de melkkoeien wordt gevoerd, de koeien $8674 \mathrm{~kg}$ melk/koe/jaar (4.39\% vet en 3.57\% eiwit) produceren en er ongelimiteerd voer aangekocht kan worden, is het aantal melkkoeien dat op basis van de hoeveelheid en kwaliteit van het eigen voer gehouden kan worden bepalend voor de hoeveelheid melk die geproduceerd kan worden. Het aantal te houden koeien is voor bouwplan 5, 6 en 7 het laagst en voor bouwplan 10 het hoogst met respectievelijk 101 en 121 koeien (Figuur 8). 


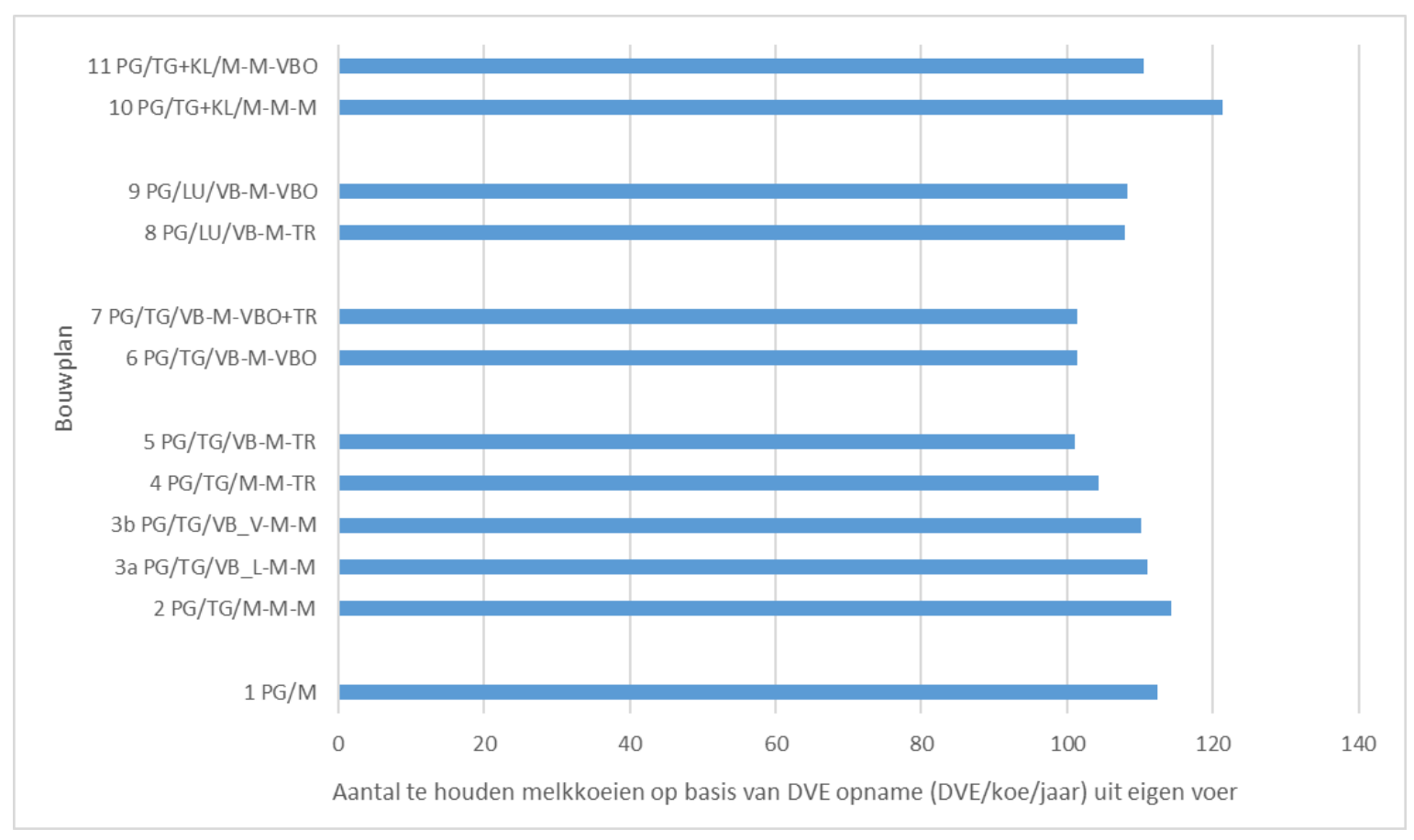

Figuur 8 Aantal te houden melkkoeien voor bouwplan $1 \mathrm{t} / \mathrm{m}$ bouwplan 11 (PG = permanent grasland, $T G=$ tijdelijk grasland, $T G+K L=$ tijdelijk gras + rode $k l a v e r, M=$ mais, $V B \_L=l a a t$ geoogste voederbiet, $V B \_V=$ vroeg geoogste voederbiet, $T R=$ triticale, $V B O=$ veldboon, $L U=$ luzerne)

\section{Droge stofopname uit eigen voer}

Het aantal melkkoeien dat gehouden kan worden wordt niet alleen bepaald door de hoeveelheid voer dat geproduceerd wordt, maar ook door de hoeveelheid droge stof die de melkkoeien daar van op kunnen nemen. De hoeveelheid droge stof die een melkkoe kan opnemen uit een bepaald voedermiddel wordt sterk beïnvloed door de verzadigingswaarde van het voedermiddel. Zie Bijlage 2 voor een overzicht van de verzadigingswaarde van het eigen voer in de bouwplannen $1 \mathrm{t} / \mathrm{m} 11$ (Figuur B2a) en de individuele voedermiddelen (Figuur B2b).

De hoeveelheid droge stof die de gemiddelde Nederlandse koe kan opnemen ( $\mathrm{kg} \mathrm{ds} \mathrm{koe/jaar)} \mathrm{uit} \mathrm{het}$ eigen voer verschilt van bouwplan tot bouwplan (Figuur 9). Ten opzichte van de bouwplannen bestaande uit gras en maïs (bouwplan 1 en 2) is de droge stof opname in de bouwplannen waar een deel van de mais door voederbieten of triticale is vervangen (bouwplan 3a, 3b en 4) hoger. In het bouwplan waarin voederbieten én triticale zijn toegevoegd (bouwplan 5 ) is de droge stofopname uit eigen voer het hoogst. In de bouwplannen waarin triticale geheel of gedeeltelijk wordt vervangen door veldbonen, is de droge stofopname uit eigen voer iets lager (bouwplan 6 en 7).

Wanneer graskuil voor een deel wordt vervangen door luzernekuil, maar er nog wel voederbiet en triticale of veldboon in het bouwplan zit (bouwplan 8 en 9) is de droge stofopname lager, maar nog wel hoger t.o.v. de bouwplannen met alleen gras en maïs (bouwplan 1 en 2). In de bouwplannen met gras/rode klaver (bouwplan 10 en 11 ) is de droge stofopname uit eigen voer lager t.o.v. de bouwplannen met gras en maïs (bouwplan 1 en 2 ).

\section{DVE opname uit eigen voer}

Niet alleen de hoeveelheid droge stof die met het eigen voer door de gemiddelde Nederlandse koe opgenomen kan worden verschilt van bouwplan tot bouwplan maar ook de hoeveelheid DVE. Niet alleen omdat de op te nemen hoeveelheid droge stof verschilt per bouwplan, maar ook omdat de hoeveelheid DVE die in de droge stof aanwezig is verschilt van bouwplan tot bouwplan (hoofdstuk 3.2.2.). In de bouwplannen bestaande uit gras en maïs (bouwplan 1 en 2) komt $64 \%$ van de op te nemen hoeveelheid DVE (g DVE/koe/jaar) uit het eigen voer (Figuur 10). In de bouwplannen waar voederbieten of triticale zijn toegevoegd (bouwplan 3a, 3b en 4) komt 70\% van het benodigde DVE uit 


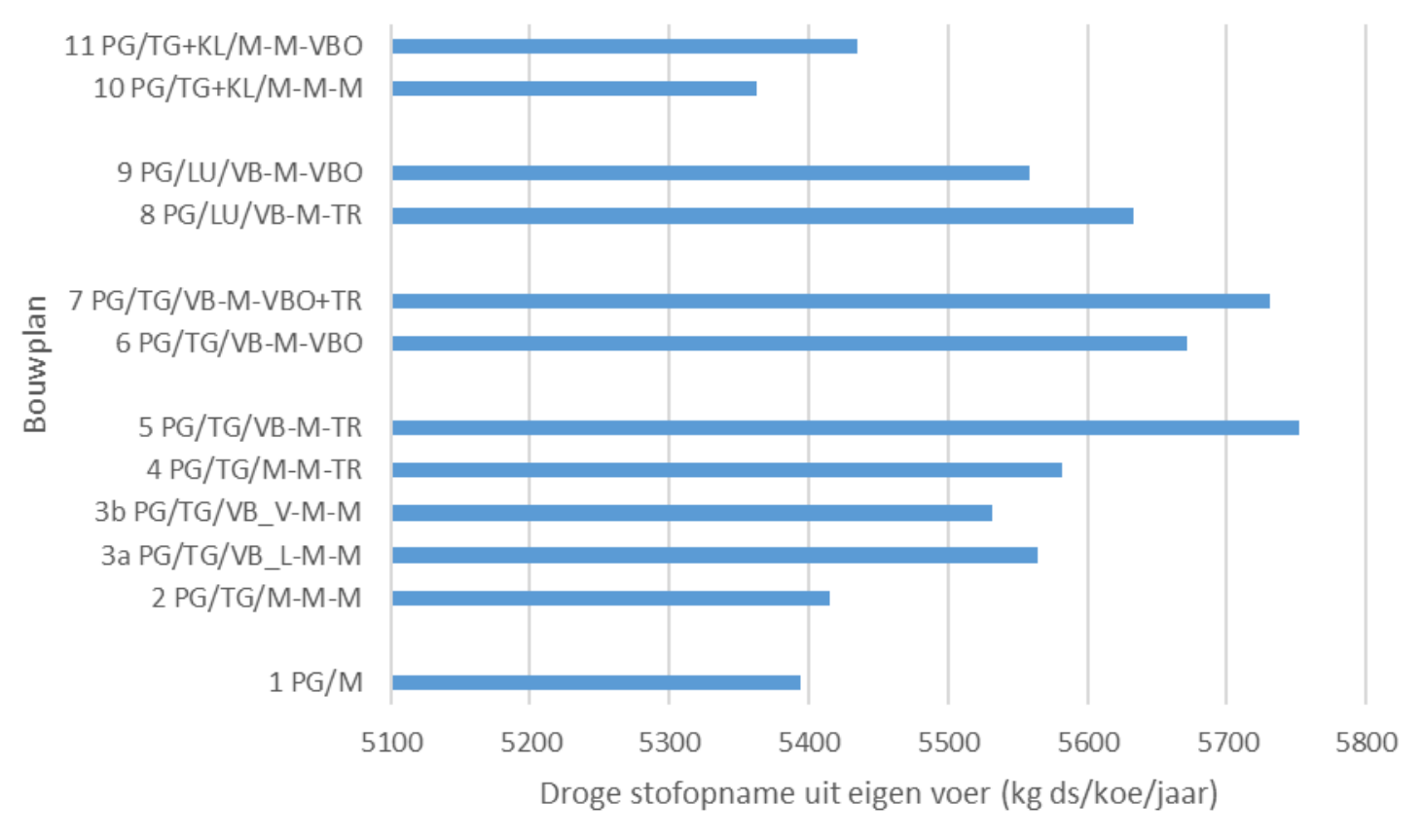

Figuur 9 Droge stofopname ( $\mathrm{kg} / \mathrm{koe} / \mathrm{jaar})$ uit eigen voer voor Bouwplan 1 tot en met 11 (PG = permanent grasland, $T G=$ tijdelijk grasland, $T G+K L=$ tijdelijk gras + rode klaver, $M=$ mais, VB_L $=$ laat geoogste voederbiet, $V B \_V=$ vroeg geoogste voederbiet, $T R=$ triticale, $V B O=$ veldboon, $L U=$ luzerne)

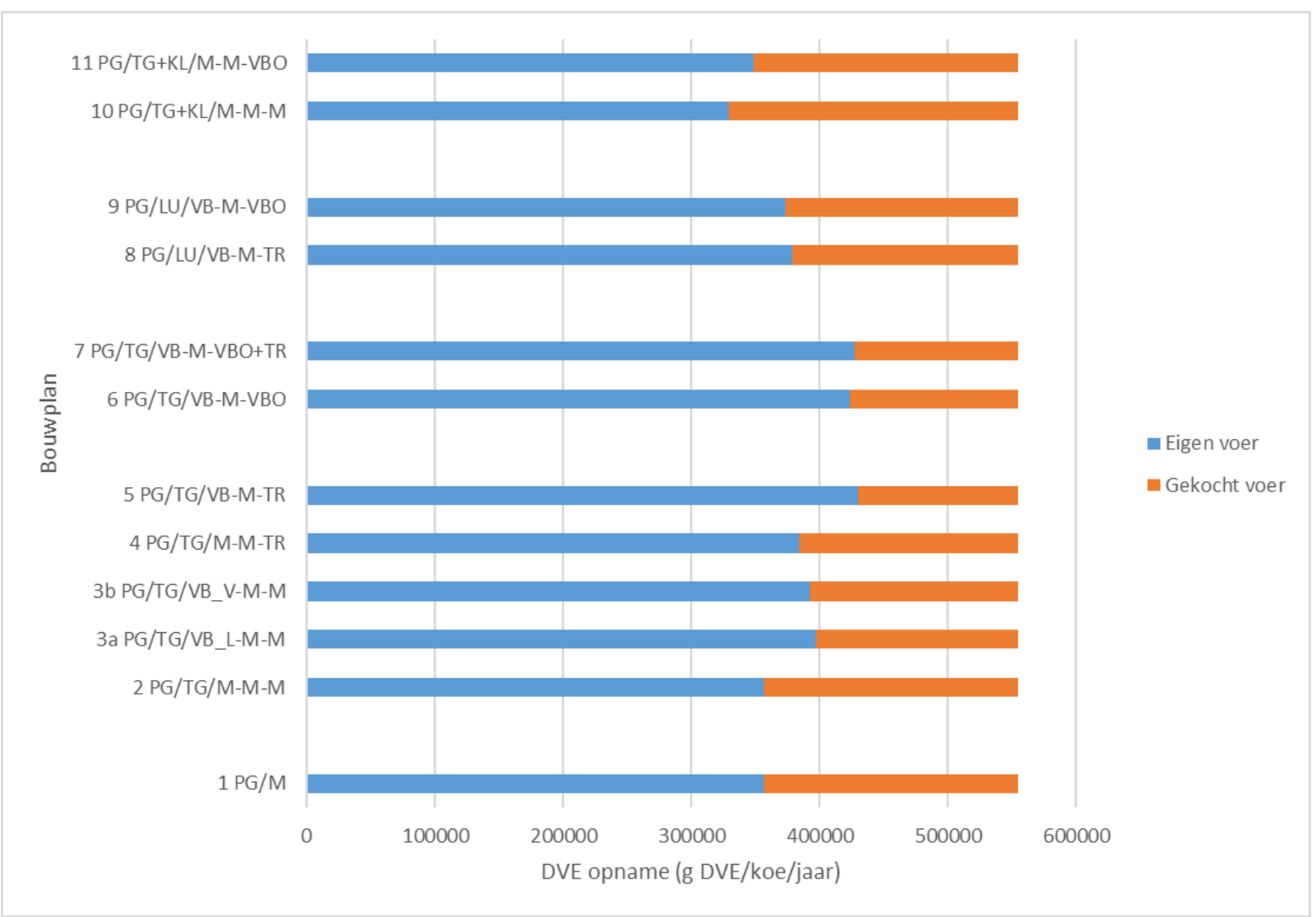

Figuur 10 DVE opname ( $g$ DVE/koe/jaar) voor Bouwplan 1 tot en met 11 gekwantificeerd naar herkomst uit eigen voer en gekocht voer $(P G=$ permanent grasland, $T G=$ tijdelijk grasland, $T G+K L=$ tijdelijk gras + rode $k$ laver, $M=$ mais, $V B \_L=$ laat geoogste voederbiet, $V B \_V=$ vroeg geoogste voederbiet, $T R=$ triticale, $V B O=$ veldboon, $L U=$ luzerne) 
het eigen voer. Wanneer voederbieten én triticale voor de korrelteelt zijn toegevoegd (bouwplan 5) of voederbieten én veldboon voor de teelt van de boon (bouwplan 6) of voederbieten en een combinatie van veldboon voor de teelt van de boon en triticale voor de korrel (bouwplan 7 ) is $77 \%$ van het benodigde DVE afkomstig uit eigen voer. In de bouwplannen waar wel voederbieten en veldboon en triticale worden verbouwd, maar de graskuil van het tijdelijke grasland is vervangen door luzernekuil (bouwplan 8 en 9) is $70 \%$ van het benodigde DVE afkomstig uit eigen voer. In bouwplan 10 waar de graskuil van het tijdelijke grasland is vervangen door gras-rode klaver kuil is $60 \%$ van het benodigde DVE afkomstig uit eigen voer. Wanneer een deel van de mais wordt vervangen door veldboon (bouwplan 11) is het aandeel van het benodigde DVE dat uit eigen voer komt (63\%) vergelijkbaar met de bouwplannen met alleen gras en mais (bouwplan 1 en 2 ).

\section{Hoeveelheid aan te kopen DVE}

Uiteindelijk bepaalt de hoeveelheid benodigd DVE (gebaseerd op het aantal te houden melkkoeien en de DVE-behoefte per melkkoe) enerzijds en de DVE opbrengst in een bouwplan anderzijds hoeveel DVE gekocht moet worden. In alle bouwplannen moet er DVE aangekocht worden (Figuur 11). Wanneer in de bouwplannen met gras en mais (bouwplan 1 en 2) graskuil wordt vervangen door grasrode klaver kuil (bouwplan 10) moet er $20 \%$ meer DVE worden aangekocht. Wanneer naast vervanging van tijdelijk gras door gras-klaver een deel van de mais wordt vervangen door veldboon (boon) (bouwplan 11) is de hoeveelheid DVE die gekocht moet worden vergelijkbaar met de bouwplannen met alleen gras en mais (bouwplan 1 en 2 ).

Door in de bouwplannen met gras en mais een deel van de mais te vervangen door voederbieten (bouwplan 3a, 3b en 4) wordt de hoeveelheid aan te kopen DVE met $20 \%$ verlaagd. De hoeveelheid aan te kopen DVE wordt verder verlaagd wanneer naast voederbieten triticale (korrel), veldboon (boon) of een combinatie van triticale en veldboon aan het bouwplan worden toegevoegd (bouwplan 5,6 en 7 ). Ten opzichte van het bouwplan met gras en mais hoeft er dan $43 \%$ minder DVE aangekocht te worden.

\section{Samenstelling aan te kopen voer}

Niet alleen de hoeveelheid DVE die met een voedermiddel wordt aangekocht is van belang, maar ook hoe een voedermiddel bijdraagt aan de onbestendig eiwit balans in het rantsoen. Het streven is dat de onbestendig eiwit balans in het rantsoen op nul komt. Bijlage 1 (Figuur B1c) geeft het OEB gehalte van individuele voedermiddelen en het DVE gehalte van individuele voedermiddelen (Figuur B1d).

Ervan uitgaande dat het aan te kopen voer bestaat uit één soort voedermiddel met $88.8 \%$ droge stof (ds) met $960 \mathrm{VEM} / \mathrm{kg}$ ds en 0,28 VW/kg ds (Tabel 6) dan geeft Figuur 12 voor bouwplan $1 \mathrm{t} / \mathrm{m} 11$ het DVE en OEB gehalte $(\mathrm{g} / \mathrm{kg} \mathrm{ds})$ dat in het aangekochte voedermiddel moet zitten om aan de behoefte van de melkkoeien te voldoen.

Voor alle bouwplannen dient een voedermiddel aangekocht te worden met een negatief OEB gehalte. Wanneer in de bouwplannen met alleen gras en mais (bouwplan 1 en 2) de graskuil van het tijdelijke grasland wordt vervangen door gras rode klaver kuil (bouwplan 10) blijven het benodigde DVE en OEB gehalte van het te kopen voer hetzelfde. Echter wanneer bovendien een deel van de mais wordt vervangen door veldboon, (bouwplan 11) dan moeten zowel het DVE gehalte als het OEB gehalte lager zijn.

Wanneer in de bouwplannen met alleen gras en mais (bouwplan 1 en 2) een deel van de mais wordt vervangen door voederbiet (bouwplan $3 a$ en $3 b$ ) kan het DVE gehalte in het aan te kopen voer lager zijn en het OEB gehalte hoger. Wordt een deel van de mais vervangen door triticale (bouwplan 4) dan blijft het benodigde DVE gehalte gelijk maar dient de OEB lager te zijn.

In de bouwplannen waar naast voederbiet ook triticale en/of veldboon wordt verbouwd (bouwplan 5, 6 en 7), zijn zowel het benodigde DVE gehalte als het benodigde OEB gehalte lager. Zit er veldboon in het bouwplan dan dient het voedermiddel een lager OEB gehalte te hebben.

Wanneer een deel van de graskuil wordt vervangen door luzernekuil (bouwplan 8 en 9) blijft het DVE gehalte gelijk aan dat van bouwplan 5,6 en 7, maar dient het OEB gehalte lager te zijn. 


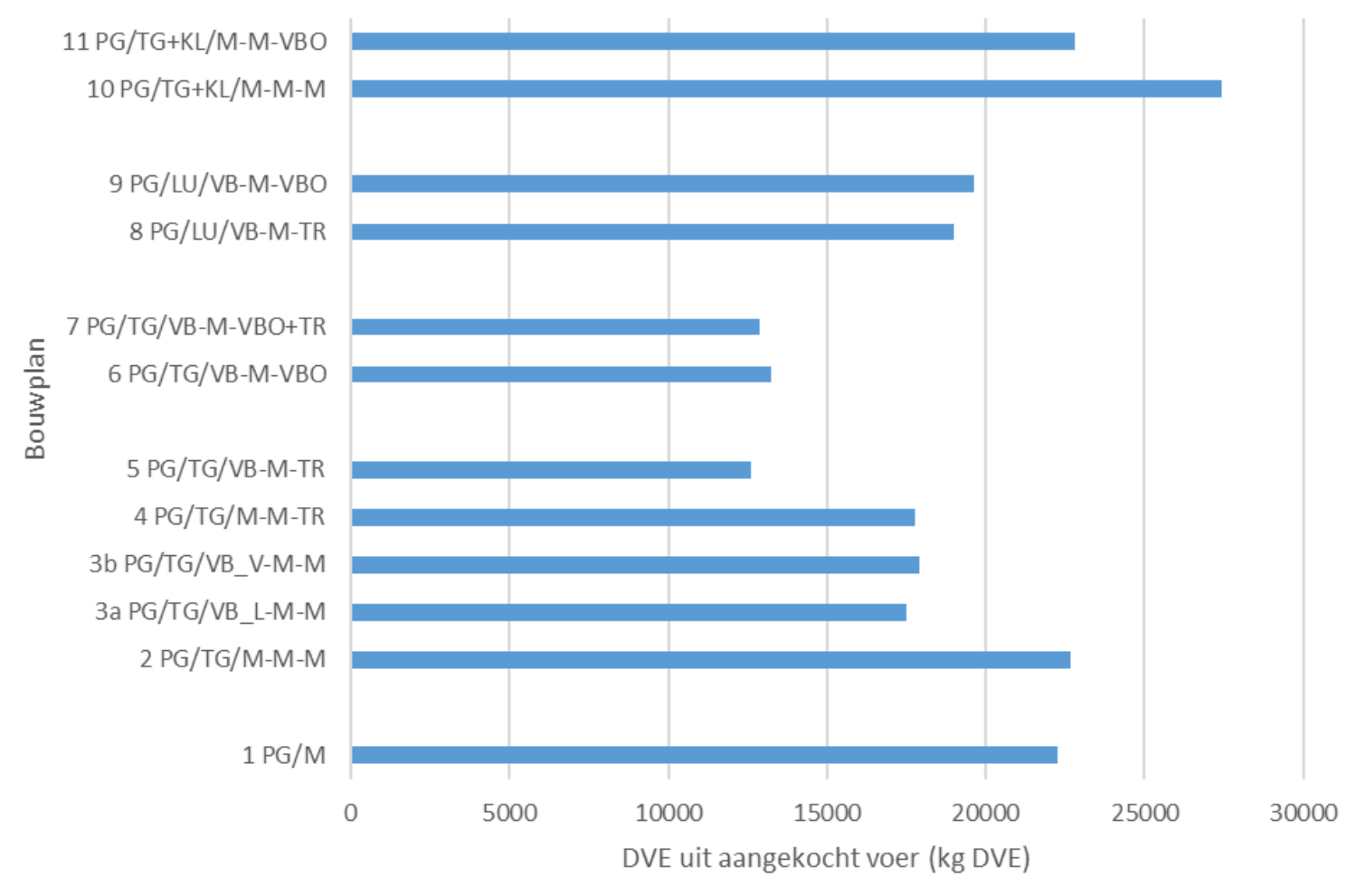

Figuur 11 Totale hoeveelheid gekocht DVE (kg/jaar)voor bouwplan $1 \mathrm{t} / \mathrm{m} 11$ (PG = permanent grasland, $T G=$ tijdelijk grasland, $T G+K L=$ tijdelijk gras + rode $k$ laver, $M=$ mais, VB_L $=$ laat geoogste voederbiet, $V B \_V=$ vroeg geoogste voederbiet, $T R=$ triticale, $V B O=$ veldboon, $L U=$ luzerne)

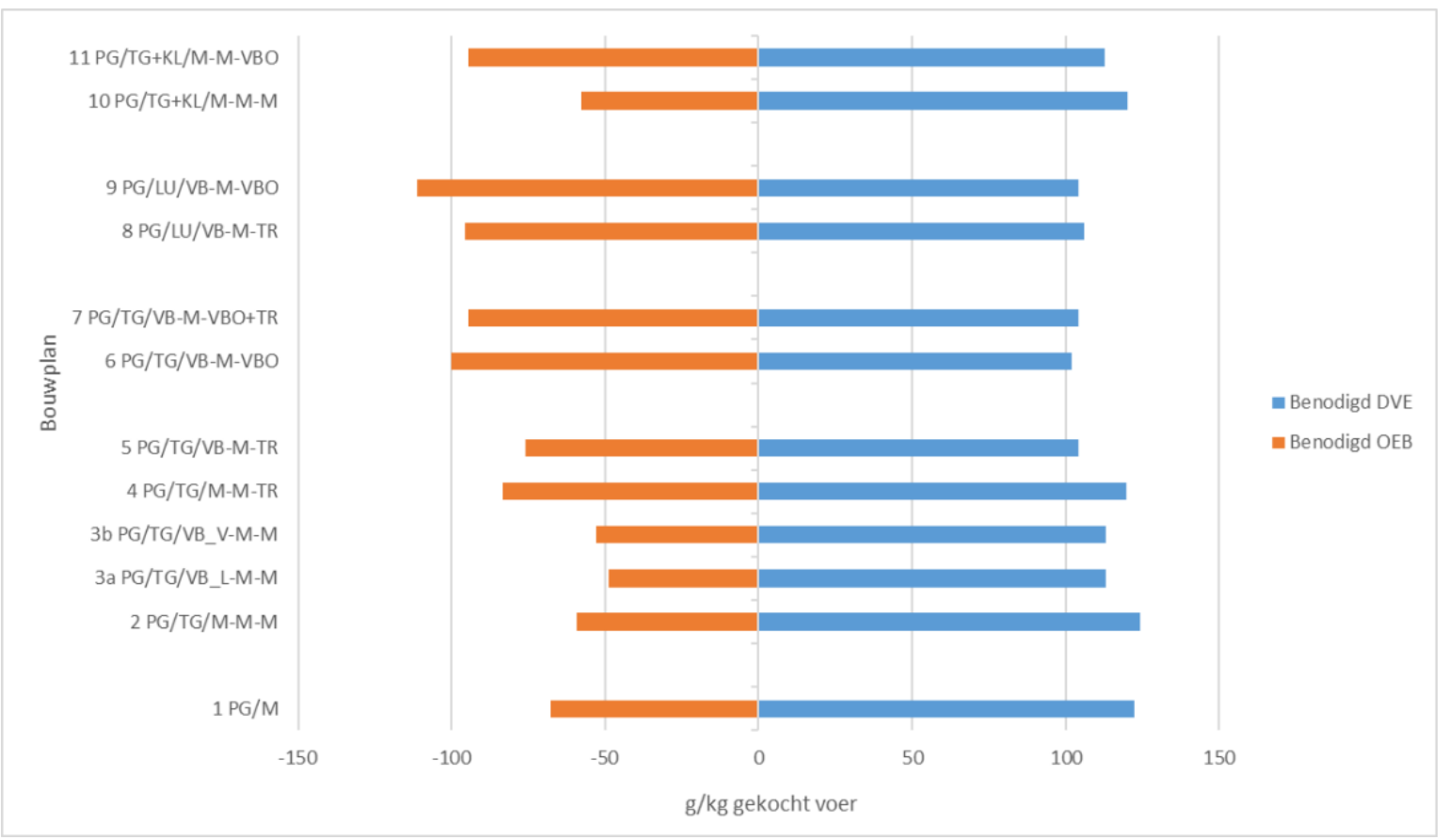

Figuur 12 Benodigd DVE- en OEB gehalte in gekocht voer ( $\mathrm{g} / \mathrm{kg} \mathrm{ds}$ ) voor de bouwplannen $1 \mathrm{t} / \mathrm{m} 11$ ( $P G=$ permanent grasland, $T G=$ tijdelijk grasland, $T G+K L=$ tijdelijk gras + rode $k$ laver, $M=$ mais, $V B \_L=$ laat geoogste voederbiet, $V B \_V=$ vroeg geoogste voederbiet, $T R=$ triticale, $V B O=$ veldboon, $L U=$ luzerne) 


\section{Discussie en conclusies}

\subsection{Discussie}

\section{Economische en milieueffecten wintergewassen}

\section{Langetermijn effecten}

Uit de studie komt naar voren dat het telen van een vroeger maisras in combinatie met een beter ontwikkeld vanggewas op de korte termijn een lager saldo geeft dan een later maisras zaaien met een matig ontwikkeld wintergewas. Op de langere termijn kan er echter sprake zijn van positieve effecten die niet in de berekeningen van deze studie zijn meegenomen o.a. door de hogere EOS-aanvoer. Zo blijkt uit eerdere studies dat de risico's van structuurschade (o.a. bodemverdichting) worden verminderd door vroeger oogsten en dat opbrengstdervingen als gevolg van verdichting bij maïs aanzienlijk kunnen zijn (10-15\%; Alblas et al., 1990). Hiermee is in deze berekeningen nog geen rekening gehouden. Ter illustratie, het saldo bij inwerken van het tussengewas is $€ 20-50$ per ha lager dan in de standaardsituatie (laat maisras en matig ontwikkeld wintergewas). Stel dat een kilo maisdrogestof $€ 0,18$ kost dan zou op termijn een extra maisopbrengst van 100-300 kg ds nodig zijn om hetzelfde saldo te realiseren dan in de standaardsituatie. Dit komt overeen een opbrengststijging van $1-2 \%$ ten opzichte van de referentiesituatie. Het economische effect van extra EOS-aanvoer is ook te benaderen door een opbrengstprijs te hanteren voor EOS. In eerdere studies is daarbij uitgegaan van een prijs van €0,20 per kg EOS (Van Dijk \& Galama, 2019; De Haan et al., 2018).

\section{Oogst wintergewas}

De berekeningen in deze studie laten zien dat het oogsten van het wintergewas een lager gewas saldo geeft als gevolg van extra oogstkosten. Echter het effect van het geoogste wintergewas op de voerkosten is hierbij niet inbegrepen.

\section{Stikstofgebruiksnorm mais}

Bij de berekeningen met tussengewassen is uitgegaan van een stikstofgebruiksnorm van $112 \mathrm{~kg} N$ per ha. Bij een norm van $140 \mathrm{~kg} \mathrm{~N}$ per ha (zandgronden buiten Noord-Brabant en Noord-Limburg) neemt het saldoverschil met de referentievarianten toe, omdat het verschil met de adviesbemesting kleiner is en het opbrengsteffect van de stikstofnalevering door het vanggewas daardoor geringer is. Hetzelfde geldt voor een situatie waarbij de dierlijke mest als rijenbemesting wordt toegediend. Ook hierdoor daalt het stikstoftekort en is het effect van de stikstofnalevering door het tussengewas op de maisopbrengst geringer.

\section{Nitraatuitspoeling}

Wintergewassen hebben de potentie de nitraatuitspoeling te verminderen doordat ze achtergebleven stikstof opnemen. Wel is het zo dat bij de keuze van vroege maisrassen de $\mathrm{N}$-opname door de mais wat lager kan zijn dan bij late maisrassen. Doordat door het vroege zaaien het wintergewas zich goed kan ontwikkelen kan deze die stikstof opnemen. Een eerdere studie naar vervroeging van de teelt van mais liet zien dat een vroegere oogst in combinatie met een betere ontwikkeld vanggewas een lagere uitspoeling gaf dan een latere oogst met een minder ontwikkeld vanggewas (Verhoeven et al., 2011).

\section{Variatie in bouwplannen}

In deze studie zijn geen sterk afwijkende bouwplannen doorgerekend t.o.v. de huidige praktijk. Door het hoge aandeel gras (voldoen aan derogatie-eis) zijn de effecten van de aanpassingen in de bouwplannen echter relatief beperkt. Toch heeft deze studie laten zien dat het opzetten van een bouwplan waarin wintergewassen worden gebruikt, maïs in vruchtwisseling wordt verbouwd en het verbouwen van andere gewassen naast gras en maïs aanknopingspunten bieden om de benutting van stikstof op het eigen bedrijf te verbeteren.

Grotere aanpassingen aan het bouwplan, zoals bijvoorbeeld het verlagen van het aandeel gras, het toepassen van andere gewassen en gewascombinaties (bijvoorbeeld kruidenrijk grasland, sorghum) kunnen mogelijk meer perspectief bieden, maar zijn niet meegenomen in deze studie. 
Evenals de mogelijkheden die vormen van samenwerking tussen akkerbouw en melkveehouderij bedrijven bieden.

\section{Melkproductie uit bouwplan}

Het doel van deze studie is het inzichtelijk maken wat de potentie van een bouwplan is voor de productie van melk. Om hierbij niet te verzanden in allerlei aannames met betrekking tot bedrijfsopzet, aantal dieren, diergroepen, rantsoenen etc. is gekozen voor het berekenen van de melkproductie voor een bedrijf van 60 ha met een stikstof bemestingsniveau volgens de gebruiksnormen en een melkproductie niveau van $8674 \mathrm{~kg} / \mathrm{koe} / \mathrm{jaar}$ waarbij het aantal te houden melkkoeien afhankelijk is gesteld van de voerproductie en er geen jongvee is.

$\mathrm{Er}$ is in deze studie niet gekeken naar de herkomst van de DVE, OEB en VW. Zo is er bijvoorbeeld niet gecontroleerd op het aandeel voederbieten in het rantsoen dat vanwege koe gezondheid beperkt is. In werkelijkheid is er op veel bedrijven jongvee aanwezig dat ook van de geteelde producten eet. Afhankelijk van het aantal stuks jongvee dat aanwezig is zal het voerverbruik per kg geproduceerde melk hoger zijn.

In deze studie is uitgegaan van een $100 \%$ VEM dekking. In de praktijk ligt de VEM dekking hoger waardoor in werkelijkheid het voerverbruik voor de melkkoeien 10 à $15 \%$ hoger ligt .

\section{Bedrijfsopzet en optimale bouwplan}

De bouwplannen zijn in deze studie vergeleken bij slechts één bedrijfsopzet (een bedrijf van 60 ha met een stikstof bemestingsniveau volgens de gebruiksnormen en een melkproductie niveau van 8674 $\mathrm{kg} / \mathrm{koe} / \mathrm{jaar}$ waarbij het aantal te houden melkkoeien afhankelijk is gesteld van de voerproductie, er is geen jongvee) en gemiddelde omstandigheden. Bij een andere bedrijfsopzet of specifieke natuurlijke omstandigheden zullen andere bouwplannen er beter uitkomen.

Dat is bijvoorbeeld het geval wanneer de stikstof bemesting limiterend is, zoals op biologische bedrijven waar geen kunstmest mag worden gebruikt. Dan zullen de bouwplannen met vlinderbloemigen het beter doen dan de andere bouwplannen omdat bij de laatste de gewasopbrengst achterblijft als gevolg van een stikstoftekort.

Op droogtegevoelige gronden bijvoorbeeld zullen de bouwplannen met de gewassen die onder droge omstandigheden blijven produceren het beter doen.

In de studie is het aantal te houden koeien afhankelijk gesteld van de voerproductie om de potentie van de bouwplannen in beeld te brengen. Bij een ander melkproductieniveau zal het aantal te houden koeien wijzigen en dus ook de totale melkproductie en de benodigde hoeveelheid aanvullend voer. Deze studie laat voor een beperkte situatie mogelijkheden zien voor het zoeken naar een optimaal bouwplan. Deze methodiek kan ook worden gebruikt voor andere bedrijfssituaties.

In werkelijkheid zal er binnen de mogelijkheden van het melkveehouderijbedrijf en de wettelijke regelgeving gekeken moeten worden welke doelen de melkveehouder wil nastreven en welk bouwplan hier bij past. De invulling van een bouwplan is sterk verbonden met het aantal te houden (melk)koeien/ha en het na te streven melkproductieniveau. Deze factoren bepalen hoeveel ruimte er in het bouwplan is om naast energie eiwit te verbouwen.

\section{Economie vruchtwisseling}

Of de mogelijkheden om de stikstof- en voerbenutting op het eigen bedrijf te verbeteren werkelijk uitgevoerd zullen gaan worden hangt o.a. af van de financiële effecten van aanpassingen van het bouwplan. Hierdoor verandert de hele bedrijfsopzet. Of bijvoorbeeld het handhaven van de melkproductie bij een bouwplan opweegt tegen de kosten van aankoop van het aanvullende DVE en de teeltkosten van de andere gewassen. Maar ook bijvoorbeeld wat de effecten zijn van het voeren van voederbieten in de gehalten vet en eiwit in de afgeleverde melk. Tenslotte verschillen ook de teeltkosten van de verschillende gewassen

De in deze studie uitgevoerde berekeningen geven geen inzicht in de financiële consequenties van een bouwplan.

\section{Continuteelt versus vruchtwisseling}

Vruchtwisseling van mais en gras heeft een positief effect op opbrengst van de mais en geeft een hogere organische stofaanvoer op het bouwlanddeel in vergelijking met continuteelt. Niet in alle situaties is dit echter mogelijk of zinvol (Van Schooten, 2020). Op lage en natte percelen is het vaak niet zinvol om vruchtwisseling toe te passen, omdat de teelt van mais op dergelijke percelen vaak 
leidt tot tegenvallende opbrengsten en er risico's zijn van schade aan der bodemstructuur in de herfst als onder natte omstandigheden moet worden geoogst. In dat geval is het beter de mais alleen te verbouwen op de hogere percelen en het gras op de lagere percelen.

Wel kan overwogen worden om op het bouwlanddeel naast mais andere voedergewassen te verbouwen.

\section{Stikstofbehoefte tijdelijk versus blijvend grasland}

In wisselbouwsystemen is de stikstofbehoefte van gras hoger dan bij blijvend grasland. Dat komt doordat er extra stikstof nodig is voor de opbouw van de nieuwe zode (Anonymus, 2019e) en doordat het stikstofleverend vermogen van de bodem lager is dan bij blijvend grasland. Dit kan worden opgevangen door de stikstofbemesting die kan worden bespaard bij de teelt van de bouwlandgewassen na het gescheurde gras, te gebruiken bij het tijdelijke grasland.

\section{Gebruik vlinderbloemigen}

\section{Combinatie met gras}

Mede vanwege de hogere $\mathrm{N}$-behoefte van nieuwe ingezaaid grasland kan worden overwogen uit te gaan van een mengsel van gras en een vlinderbloemige zoals rode klaver. De berekeningen lieten zien dat met gras + rode klaver een hogere drogestofopbrengst kan worden behaald dan met alleen gras, het verschil in voederwaardeopbrengst is echter gering door de lagere VEM- en DVE-waarde van de gras-klaverkuil. Echter, in situaties met een tekort aan stikstof kunnen gras-klaver-mengsels een meerwaarde hebben, omdat het verschil met gangbare grasmengsels dan mogelijk groter zal zijn dan nu aangehouden in de berekeningen omdat bij lagere N-bemestingsniveau's de opbrengst en kwaliteit van de gangbare mengsels lager zal zijn.

Andere opties die niet zijn doorgerekend zijn bijvoorbeeld een mengsel van gras en erwten. Het eiwiteffect beperkt zich in dit geval tot het jaar van inzaai en met name de eerste snede. Na maaien komen de erwten niet terug. Ook mengsels van gras en luzerne kunnen een optie zijn.

\section{Luzerne}

In deze studie is luzerne als luzernekuil ingerekend. In de praktijk wordt luzerne ook vaak als kunstmatig gedroogd product vervoederd. Kunstmatig gedroogde luzerne heeft een 2 keer zo hoog DVE gehalte als luzernekuil en een lager OEB gehalte (Bijlage 1) waardoor de mogelijkheden van luzerne voor gebruik in een bouwplan in deze studie mogelijk wordt onderschat.

Winter- versus zomerteelt zaadleguminosen

Voor de zaadleguminosen is uitgegaan van winterveldbonen. Dit gewas is op zand- en lössgrond als hoofdgewas na mais officieel niet toegestaan. Er kan ook worden gekozen voor zomerveldbonen. Dat gewas is wel toegestaan, omdat er dan nog een verplicht vanggewas mogelijk is tussen de oogst van de mais en de inzaai van de bonen in het voorjaar. De opbrengst van zomerveldboon is lager dan die van winterveldboon.

\section{Voederwaardeopbrengst (andere) granen}

In de berekeningen is bij graan uitgegaan van triticale. Een alternatief voor triticale is wintergerst. Uit de CVB-gegevens met betrekking tot voederwaarde blijkt dat wintergerst een iets lagere VEM-waarde heeft dan wintertarwe, terwijl de DVE-waarde vergelijkbaar is. Hierdoor is de DVE/VEM-verhouding iets gunstiger dan bij wintertarwe (Bijlage 1).

\section{Andere grasmengsels}

Bij grasland is uitgegaan van gangbare mengsels voor gemengd gebruik (weiden en maaien) met een hoog aandeel Engels raaigras (Lolium perenne).

In een aantal bouwplannen is het tijdelijke grasland ingerekend voor een maairegime. In deze situatie is het gebruik van gras-rode klaver mengsels een mogelijkheid (bouwplan 10 en 11), maar ook het gebruik van specifieke grasrassen zoals Festulolium-typen.

Festulolium is een kruising tussen festuca's (beemdlangbloem of rietzwenkgras) en Lolium typen (Engels raaigras of Italiaans raaigras). Van projectpartner DLF is informatie verkregen over de opbrengst en voederwaarde van Festulolium-mengsels in vergelijking met gangbare mengsels. Er zijn gegevens verstrekt van zes meerjarige maaiproeven, waarbij Festulolium raaigrastype en Festulolium rietzwenktype zijn vergeleken met Engels raaigras. De drogestofopbrengst van het Festulolium 
raaigrastype was 9-33\% hoger dan die van Engels raaigras. Gemiddelde over alle zes proeven bedroeg de extra opbrengst $24 \%$. Bij het Festulolium rietzwenktype was de opbrengst gemiddeld over drie proeven $27 \%$ hoger dan Engels raaigras (17-39\% extra opbrengst). De verteerbaarheid (bepaald in vier proeven) was gemiddeld zo'n $8 \%$ (uiteenlopend van 1-13\%) lager dan die van Engels raaigras. Er waren geen gegevens over eiwitgehalte beschikbaar.

Om aan andere doelen als diergezondheid, biodiversiteit, droogtetolerantie of vogelbeheer te voldoen kan (een deel van) het grasland worden vervangen door kruidenrijk grasland. Momenteel wordt kruidenrijk grasland op twee manieren benaderd. Enerzijds de mengsels van kruiden en gras met een hoge opbrengst die vergelijkbaar is met gangbare mengsels. Deze zijn volop in onderzoek wat betreft samenstelling en management. Anderzijds de van nature kruidenrijke graslanden. Hiervan is de opbrengst fors lager dan van de gangbare mengsels. En zijn voederwaarde en management van deze graslanden bekend (Geerts et al., 2014).

\subsection{Conclusies}

\subsubsection{Continuteelt mais met wintergewassen}

- Het telen van een wintergewas waarbij wordt uitgegaan van een vroegere maisoogst leidt op de korte termijn tot een lager saldo van de mais. Het tijdig inwerken van het wintergewas (functie als vanggewas) is daarbij gunstiger dan het oogsten ervan (functie als tussengewas). Dit is vooral een gevolg van de extra oogstkosten van het tussengewas.

- Het inwerken van het wintergewas geeft de hoogste EOS-aanvoer. Op de langere termijn heeft dit een positief effect op de organische stofvoorziening.

\subsubsection{Vruchtwisseling met andere gewassen}

\section{Gedeeltelijk vervangen van mais door voederbieten}

Het deels vervangen van mais door voederbieten leidt tot

- een hogere energie- (VEM) en eiwitproductie (zowel RE als DVE),

- een hogere droge stofopname ( $\mathrm{kg} \mathrm{ds} / \mathrm{koe} / \mathrm{jaar}$ ) uit eigen voer,

- een iets lagere melkproductie (ton/jaar),

- een hoger aandeel melk dat is geproduceerd uit eigen voer,

- $\quad$ een lagere hoeveelheid aan te kopen DVE (kg/jaar) met

- $\quad$ in het aan te kopen voer een lager DVE gehalte en een hoger (minder negatief) OEB gehalte.

\section{Gedeeltelijk vervangen van mais door veldboon}

Het deels vervangen van mais door veldboon leidt tot

- een lagere VEM-productie, een hogere ruw eiwitproductie, een lagere DVE productie,

- $\quad$ een hogere droge stofopname ( $\mathrm{kg} \mathrm{ds} / \mathrm{koe} / \mathrm{jaar})$ uit eigen voer,

- een lagere melkproductie (ton/jaar),

- $\quad$ een hoger aandeel melk dat is geproduceerd uit eigen voer,

- $\quad$ een lagere hoeveelheid aan te kopen DVE (kg/jaar) met

- $\quad$ in het aan te kopen voer een lager DVE gehalte en een lager (meer negatief) OEB gehalte.

\section{Triticale versus veldboon}

Het vervangen van veldboon door triticale leidt tot

- $\quad$ een iets hogere VEM-productie, een lagere RE productie maar een iets hogere DVE productie.

- $\quad$ een hogere droge stofopname ( $\mathrm{kg} \mathrm{ds} / \mathrm{koe} / \mathrm{jaar}$ ) uit eigen voer,

- een vergelijkbare melkproductie (ton/jaar),

- een vergelijkbaar aandeel melk dat is geproduceerd uit eigen voer,

- $\quad$ een iets lagere hoeveelheid aan te kopen DVE ( $\mathrm{kg} / \mathrm{jaar}) \mathrm{met}$

- $\quad$ in het aan te kopen voer een iets hoger DVE gehalte en een hoger (minder negatief) OEB gehalte. 


\section{Gedeeltelijk vervangen mais door voederbiet en triticale}

Het deels vervangen van mais door voederbiet en triticale leidt tot

- een lagere VEM-productie, een lagere ruw eiwitproductie, maar een hogere DVE productie,

- een hogere droge stofopname ( $\mathrm{kg} \mathrm{ds} / \mathrm{koe} / \mathrm{jaar}$ ) uit eigen voer,

- een lagere melkproductie (ton/jaar),

- een hoger aandeel melk dat is geproduceerd uit eigen voer,

- een lagere hoeveelheid aan te kopen DVE (kg/jaar) met

- in het aan te kopen voer een lager DVE gehalte en een iets lager (meer negatief) OEB gehalte.

\section{Voederbiet en triticale versus voederbiet en veldboon}

Het deels vervangen van voederbiet en triticale door voederbiet en veldboon leidt tot

- een iets lagere VEM-productie, een hogere ruw eiwitproductie, maar een iets lagere DVE productie,

- een lagere droge stofopname ( $\mathrm{kg} \mathrm{ds} / \mathrm{koe} / \mathrm{jaar})$ uit eigen voer,

- een vergelijkbare melkproductie (ton/jaar),

- een vergelijkbaar aandeel melk dat is geproduceerd uit eigen voer,

- een iets hogere hoeveelheid aan te kopen DVE ( $\mathrm{kg} / \mathrm{jaar})$ met

- in het aan te kopen voer een lager DVE gehalte en een lager (meer negatief) OEB gehalte.

\section{Vervangen van tijdelijk gras door gras-rode klaver}

Vervanging van tijdelijk gras door gras-rode klaver leidt tot

- een lagere VEM-productie, een licht hogere RE productie maar een licht lagere DVE productie,

- een lagere droge stofopname ( $\mathrm{kg} \mathrm{ds} / \mathrm{koe} / \mathrm{jaar}$ ) uit eigen voer,

- een hogere melkproductie (ton/jaar),

- een lager aandeel melk dat is geproduceerd uit eigen voer,

- een hogere hoeveelheid aan te kopen DVE ( $\mathrm{kg} / \mathrm{jaar})$ met

- in het aan te kopen voer een iets lager DVE gehalte en een lager (meer negatief) OEB gehalte.

\section{Vervangen van tijdelijk gras door luzerne (kuil)}

Vervanging van tijdelijk gras door luzerne (kuil) leidt tot

- een lagere VEM-productie, een licht hogere RE productie maar een licht lager DVE productie.

- een hogere droge stofopname ( $\mathrm{kg} \mathrm{ds} / \mathrm{koe} / \mathrm{jaar}$ ) uit eigen voer,

- een lagere melkproductie (ton/jaar),

- een hoger aandeel melk dat is geproduceerd uit eigen voer,

- een lagere hoeveelheid aan te kopen DVE (kg/jaar) met

- in het aan te kopen voer een lager DVE gehalte en een lager (meer negatief) OEB gehalte.

\section{Eiwit en energie in het bouwplan}

- Voor melkproductie is DVE productie/ha bepalend, niet RE productie/ha.

- Naast VEM productie/ha en DVE productie/ha is de VW productie/ha doorslaggevend voor de hoeveelheid droge stof de koeien van het voer kunnen opnemen.

- In de situatie dat het aankopen van DVE ongelimiteerd kan, geven de bouwplannen waarin de meeste energie verbouwd wordt de hoogste melkproductie.

- De in deze studie gekozen gewassen zijn interessant voor voerproductie op het melkveebedrijf. De uitdaging is om de gewassen in de meest gunstige verhouding te telen zodat zowel de energieproductie op peil blijft en er zoveel mogelijk DVE verbouwd kan worden met een lage VW.

\section{Organische stofvoorziening}

- De verschillen in totale EOS-aanvoer tussen de bouwplannen zijn gering. Dat komt door het hoge aandeel gras ( $80 \%$ in de meeste rotaties) dat een hoge aanvoer van EOS geeft op gewasniveau. In vergelijking met de situatie met alleen mais en gras neemt de EOS-aanvoer licht toe in de varianten met andere bouwlandgewassen. De aanvoer is het hoogst in de rotaties met triticale. 
- Hoewel de totale EOS-aanvoer weinig verschilt tussen de bouwplannen, verbetert bij wisselbouw met gras wel de situatie voor het bouwland. De EOS-aanvoer voor het wisselbouw-deel van het bedrijf is hoger dan bij de continuteelt van mais. 


\section{Literatuur}

Anonymus, 2016a. Tabellenboek Veevoeding 2016. Voedernormen Rundvee, Schapen, Geiten en voederwaarden voedermiddelen voor Herkauwers. CVB-reeks nr. 52. November 2016. http://www.cvbdiervoeding.nl/pagina/10081/downloads.aspx

Anonymus, 2016b. Kwantitatieve Informatie Veehouderij 2016-2017. Wageningen Livestock Research, Handboek 31.

Anonymus, 2018. CVB Veevoedertabel 2018. Chemische samenstellingen en nutritionele waarden van voedermiddelen. September 2018. CVB tabel 2018 versie 2. www.cvbdiervoeding.nl.

Anonymus, 2019a. https://opendata.cbs.nl/statline

Anonymus, 2019b. www.voederwaardeprijzen.nl

Anonymus, 2019c. www.handboeksnijmais.nl

Anonymus, 2019d. www.handboekbodemenbemesting.nl

Anonymus, 2019e. www.bemestingsadvies.nl

De Boer, H.C., G. van Duinkerken, A.P. Philipsen \& H.A. van Schooten, 2003. Alternatieve voedergewassen. Praktijkrapport Rundvee nr. 27, Lelystad, Praktijkonderzoek Veehouderij.

De Haan, Janjo, Marie Wesselink, Wim van Dijk, Harry Verstegen, Willem van geel \& Wim van den Berg, 2018. Effect van organische stofbeheer op opbrengst, bodemkwaliteit en stikstofverliezen op een zuidelijke zandgrond. Resultaten van de gangbare bedrijfssystemen van het project Bodemkwaliteit op zand in de periode 2011-2016. Wageningen Research, rapport WPR-754.

Geerts, Rob, Hein Korevaar, Arend Timmerman, 2014. Kruidenrijk grasland. Meerwaarde voor vee, bedrijf en weidevogel. Brochure Praktijknetwerk 'Natuurlijk' kruidenrijk gras voor de veehouderij. https://edepot.wur.nl/295728

Latré, J., E. Dupon, J. De Boever, A. De Vliegher, G. Haesaert, 2018. Voederbiet, een gewas met een toekomst voor een meer duurzame veehouderij. Presentatie bijeenkomst NVWV. https://nvwv.nl/node/890

Prins, U. \& M. van Krimpen, 2007. Handboek Peulvruchten voor krachtvoer. Krachtvoereiwit voor melkkoeien, melkgeiten, kippen en varkens. Louis Bolk Instituut.

Schils, R. L. M., Höglind, M., Curth-van Middelkoop, J. C., Holshof, G., Verloop, J., Rijk, H. C. A., ... van Ittersum, M. K. (2018). Framework for yield gap analysis in grasslands. In B. Horan, D. Hennessy, M. O’Donovan, E. Kennedy, B. McCarthy, J. A. Finn, \& B. O’Brien (Eds.), Sustainable meat and milk production from grasslands: Proceedings of EGF general meeting, Cork, June 1721, 2018 (pp. 90-92). (Grassland Science in Europe; Vol. 23). Wageningen: Wageningen Academic Publishers.

Schröder, J.J., L.B. Sebek, J. Oenema, J.G. Conijn, Th. Vellinga \& J. de Boer. 2019. Rekenregels van de kringloopwijzer 2018. Achtergronden van BEX, BEA, BEN, BEP en BEC; actualisatie van de 2017-versie. Wageningen Research, Rapport WPR 883. https://edepot.wur.nl/475701

Van Dijk, W., J.J. Schröder, L.B.J. Sebek, J. Oenema, J.G. Conijn, Th.V. Vellinga, J. de Boer, M.H.A. de Haan \& J. Verloop, 2020. Rekenregels van de kringloopwijzer 2019. Achtergronden van BEX, BEA, BEN, BEP en BEC; actualisatie van de 2018-versie. Wageningen Research, Rapport WPR-956, 130 bl.

Van der Schans, D.A. 1998. De teelt van luzerne. Teelthandleiding nr. 84, Praktijkonderzoek voor de Akkerbouw en Vollegrondsgroenteteelt.

Van Dijk, W. \& P. Galama, 2019. De maat van mest. Perspectief van mestbewerking op de boerderij vanuit belang akkerbouwer en melkveehouder. Wageningen Research, Rapport 547

Van Eekeren, N.J.M., D.W. van Liere, F.T. de Vries, M. Rutgers, R.G.M. de Goede, L. Brussaard. 2009. A mixture of grass and clover combines the positive effects of both plant species on selected soil biota. Applied Soil Ecology. 42:254-263. www.klaverklimaat.nl

Van Schooten, H.,, 2020. Duurzame continuteelt mais -Nog steeds een optie, maar welk vakmanschap is nodig. Presentatie Themadag Commissie Bemesting Grasland en Voedergewassen 'Mais en gras: in vruchtwisseling of continuteelt', 6 februari 2020, Nijkerk.

Verhoeven, J., C. Bus, W. van Dijk, W. van Geel, H. van Schooten, J. Schröder \& R. Wustman, 2011. Teeltvervroeging bij consumptieaardappel en snijmaïs op zand ten behoeve van vanggewassen. Deskstudie naar mogelijkheden en beperkingen. Praktijkonderzoek Plant en Omgeving. 
Wolf, Pieter de, Joanneke Spruijt en Marcia Stienezen, 2017. Gras en maïs in vruchtwisseling; een overzicht van bestaande kennis. Wageningen Research, WPR-rapport 748.

Zom, Ronald. 2014. The development of a model for the prediction of feed intake and energy partitioning in dairy cows. PhD thesis, Wageningen University, Wageningen, NL (2014) ISBN 97894-6257-044-3 https://edepot.wur.nl/312579 


\section{Bijlage 1 Voederwaardekenmerken}

Voederwaarde kenmerken voor deze studie relevante producten.

Bron CVB-veevoedertabel-2018-editie-2.

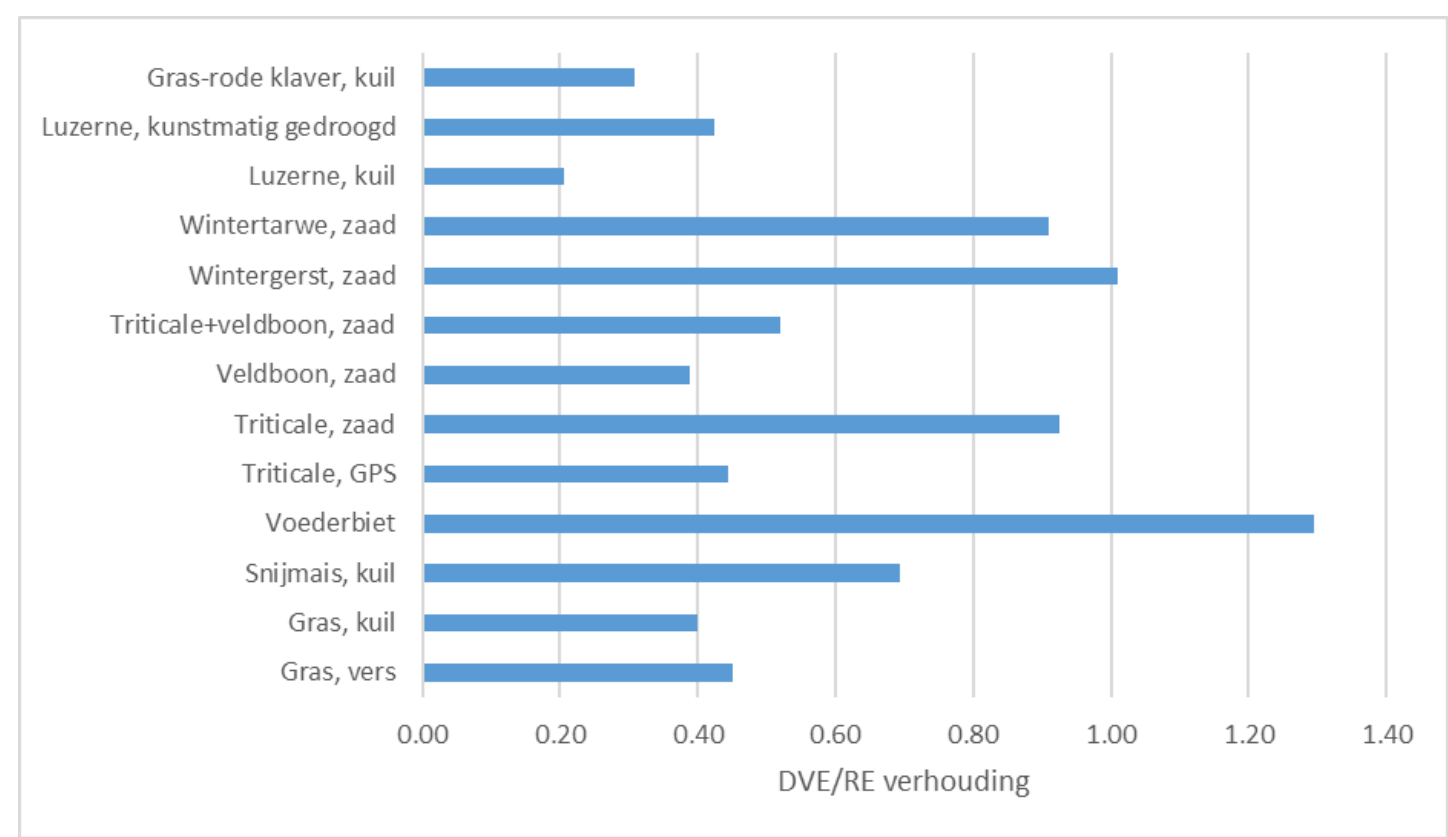

Figuur B1a $D V E / R E$ verhouding. $R E=$ Ruw eiwit. $D V E=$ Darm verteerbaar eiwit.

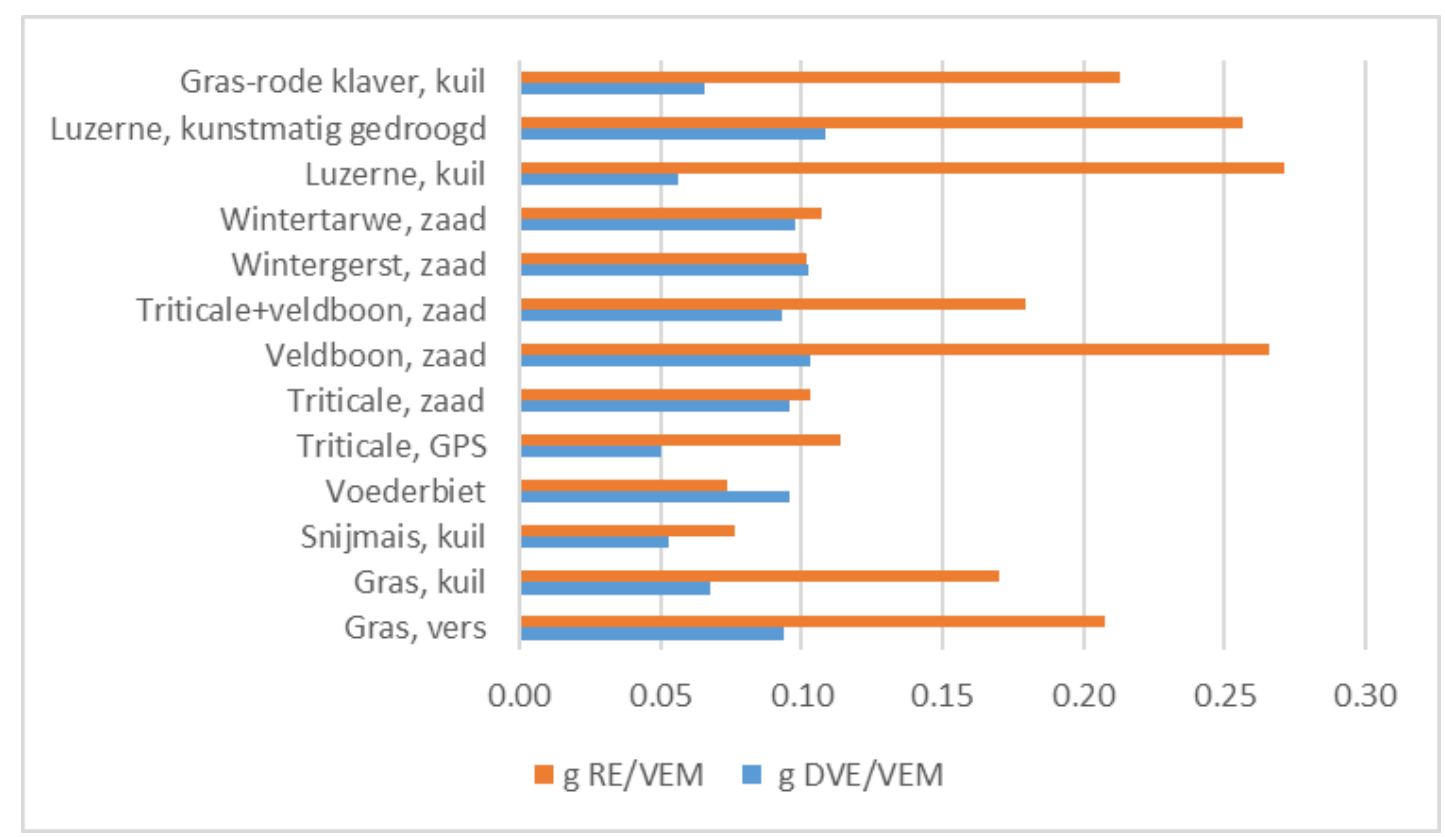

Figuur B1b Eiwit-energie verhouding, uitgedrukt in RE/VEM en DVE/VEM. RE = Ruw eiwit. DVE = Darm verteerbaar eiwit. VEM $=$ Voedereenheid Melk 
Gras-rode klaver, kuil Luzerne, kunstmatig gedroogd

Luzerne, kuil

Wintertarwe, zaad

Wintergerst, zaad

Triticale+veldboon, zaad

Veldboon, zaad

Triticale, zaad

Triticale, GPS

Voederbiet

Snijmais, kuil

Gras, kuil

Gras, vers

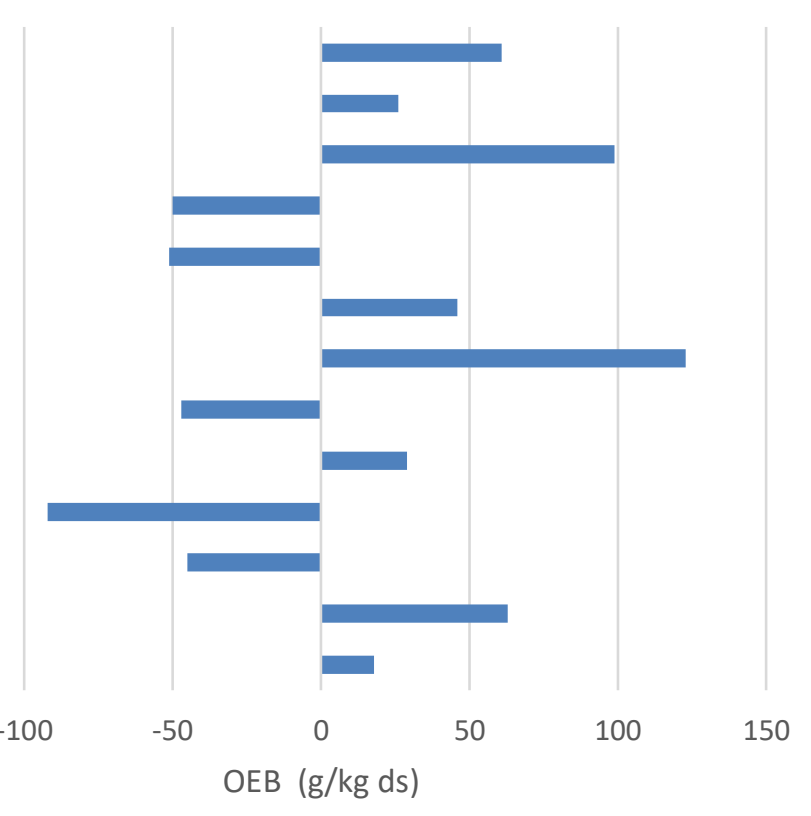

Figuur B1C OEB gehalte, $\mathrm{g} / \mathrm{kg}$ droge stof. OEB = onbestendig eiwit balans.

Gras-rode klaver, kuil Luzerne, kunstmatig gedroogd

Luzerne, kuil

Wintertarwe, zaad

Wintergerst, zaad

Triticale+veldboon, zaad

Veldboon, zaad

Triticale, zaad

Triticale, GPS

Voederbiet

Snijmais, kuil

Gras, kuil

Gras, vers
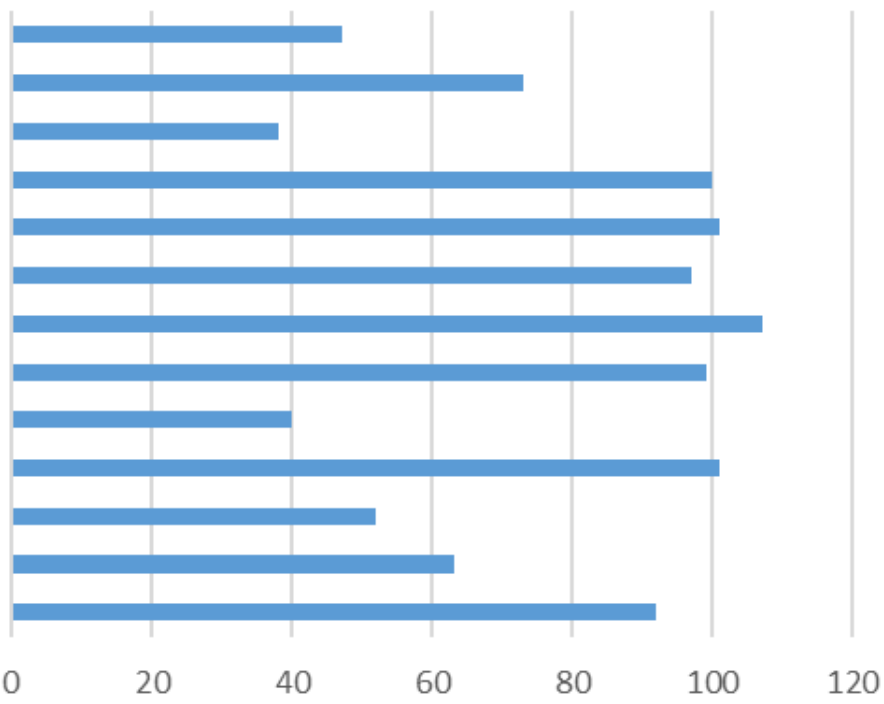

DVE g/kg ds)

Figuur B1d DVE gehalte $(\mathrm{g} / \mathrm{kg} d s)$. DVE = Darm verteerbaar eiwit. 


\section{Bijlage 2 Verzadigingswaarde}

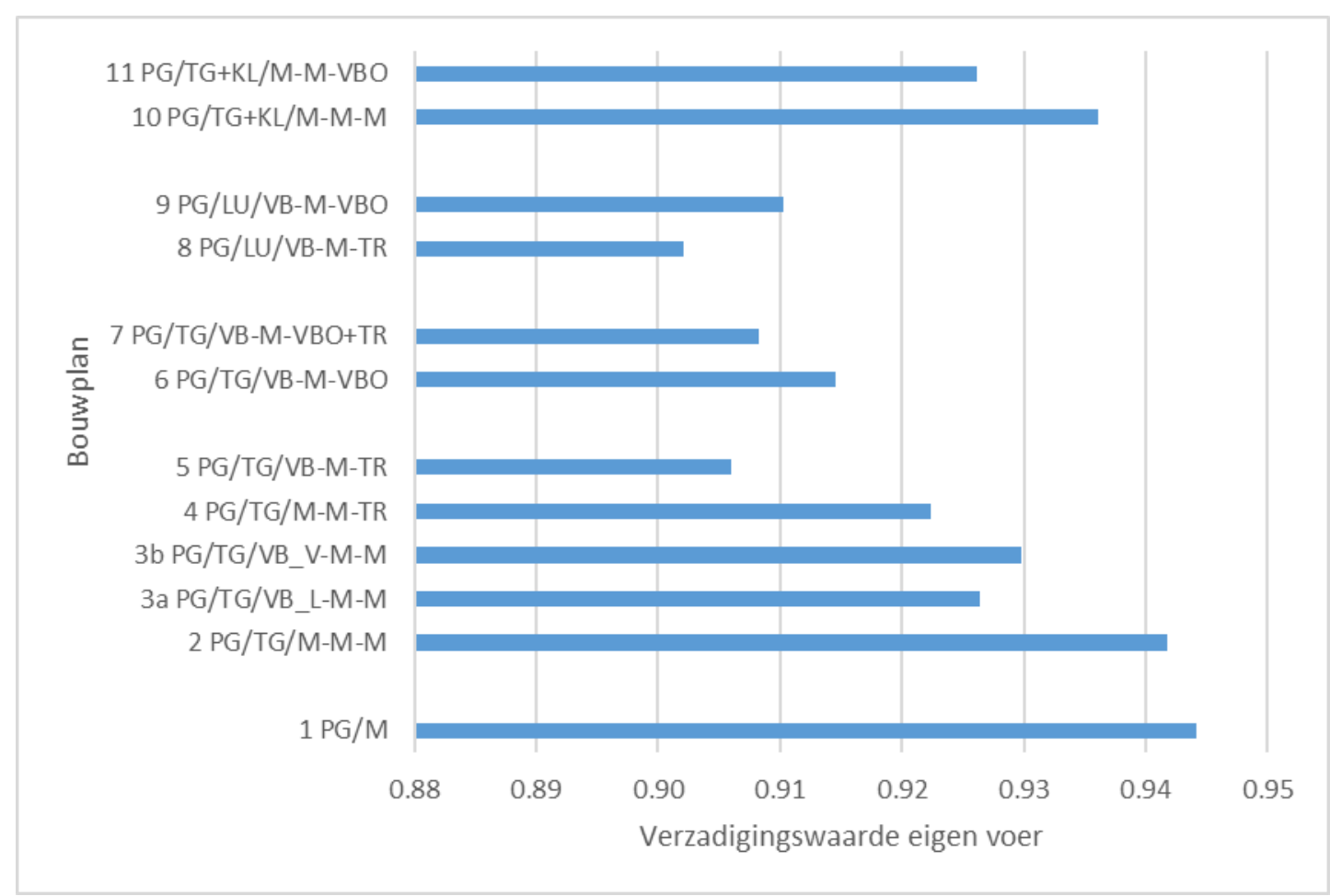

Figuur B2a Verzadigingswaarde voor Bouwplan 1 tot en met 11 (PG = permanent grasland, TG = tijdelijk grasland, $T G+K L=$ tijdelijk gras + rode klaver, $M=$ mais, $V B \_L=$ laat geoogste voederbiet, $V B \_V=$ vroeg geoogste voederbiet, $T R=$ triticale, $V B O=$ veldboon, $L U=$ luzerne)

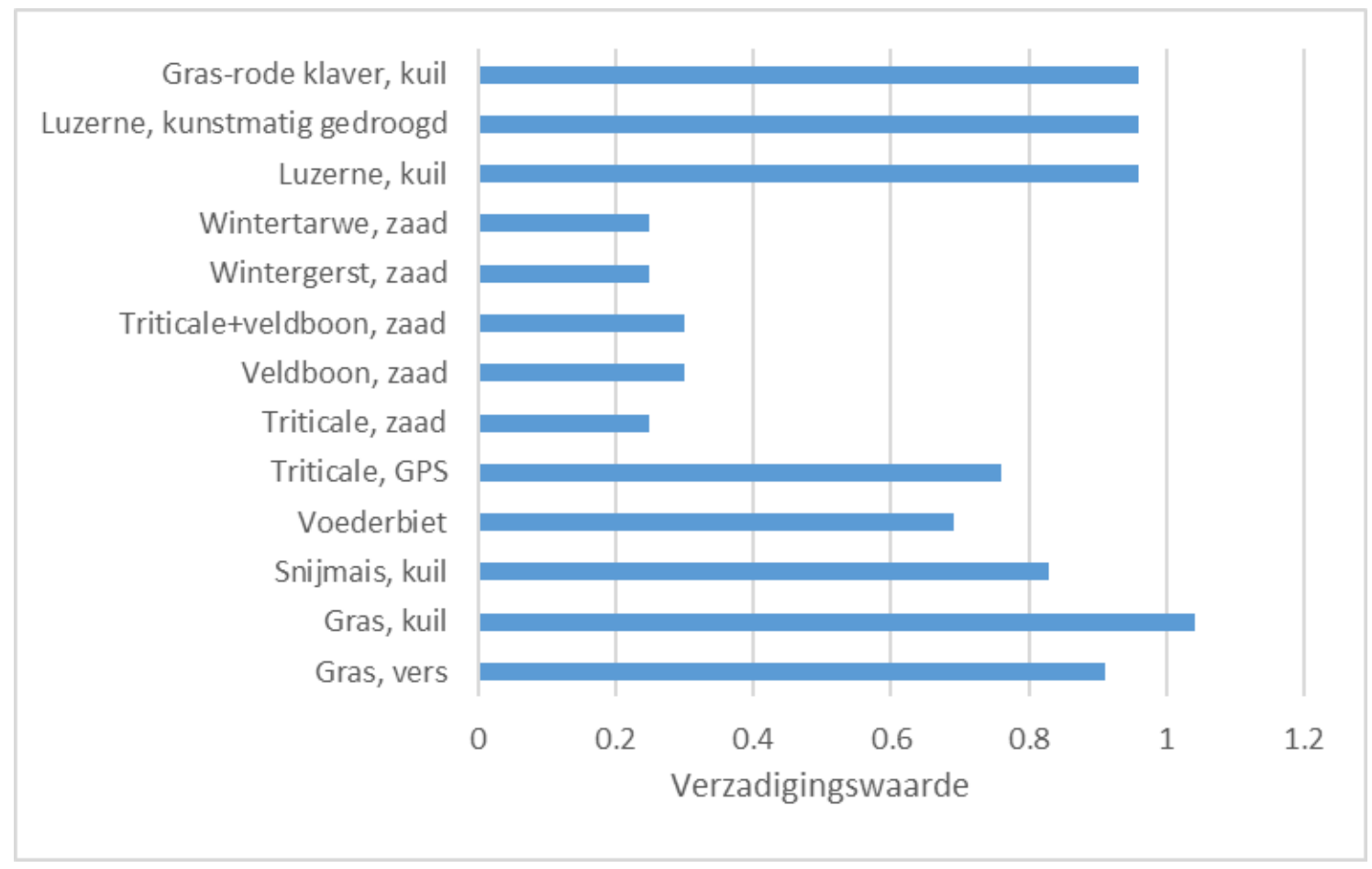

Figuur B2b Verzadigingswaarde voor deze studie relevante voedermiddelen. Bron: CVBveevoedertabel-2018-editie-2 


\section{Bijlage 3 Uitgangspunten berekeningen rantsoenen melkvee}

Tabel B3a Opbouw energie behoefte melkkoe in voedereenheden melk (VEM)*

\begin{tabular}{lll}
\hline VEM melk + onderhoud/jaar & 5920 & $($ kVEM/koe/jaar $)$ \\
VEM-onderhoud droogstand/jaar & 266 & $($ kVEM/koe/jaar $)$ \\
VEM-dracht & 101 & $($ kVEM/koe/jaar $)$ \\
VEM-behoefte jeugdgroei & 101 & $(\mathrm{kVEM} / \mathrm{koe} / \mathrm{jaar})$ \\
VEM-activiteit & 194 & $(\mathrm{kVEM} / \mathrm{koe} / \mathrm{jaar})$ \\
VEM-toeslag beweiding & 40 & $(\mathrm{kVEM} / \mathrm{koe} / \mathrm{jaar})$ \\
VEM-Toeslag NEB & 93 & $(\mathrm{kVEM} / \mathrm{koe} / \mathrm{jaar})$ \\
\hline VEM-behoefte Totaal & $\mathbf{6 7 1 5}$ & $\mathbf{( k V E M / k o e / j a a r )}$
\end{tabular}

* Berekeningen volgens Tabellenboek Veevoeding 2016 (Anonymus 2016)

Tabel B3b Opbouw DVE behoefte melkkoe in eenheden darm verteerbaar eiwit (DVE)*

\begin{tabular}{lll}
\hline DVE melk+onderhoud/jaar & 529134 & (DVE/koe/jaar) \\
DVE-onderhoud droogstand/jaar & 6545 & (DVE/koe/jaar) \\
DVE-dracht & 13344 & (DVE/koe/jaar) \\
DVE-behoefte jeugdgroei & 5723 & (DVE/koe/jaar) \\
\hline DVE-behoefte Totaal & $\mathbf{5 5 4 7 4 6}$ & (DVE/koe/jaar)
\end{tabular}

* Berekeningen volgens Tabellenboek Veevoeding 2016 (Anonymus 2016)

Tabel B3c Gebruikte gegevens ter bepaling Verzadigingwaarde eenheden (VW-eenheid) bouwplan*

\begin{tabular}{lll}
\hline Voeropname capaciteit/lactatie & 6382 & (Verzadingswaarde-eenheden/lactatie) \\
Voeropname capaciteit/jaar & 5546 & (Verzadingswaarde-eenheden/jaar) \\
VEM/VW-eenheid & 1211 & \\
\hline
\end{tabular}

* Berekeningen volgens Tabellenboek Veevoeding 2016 (Anonymus 2016) 


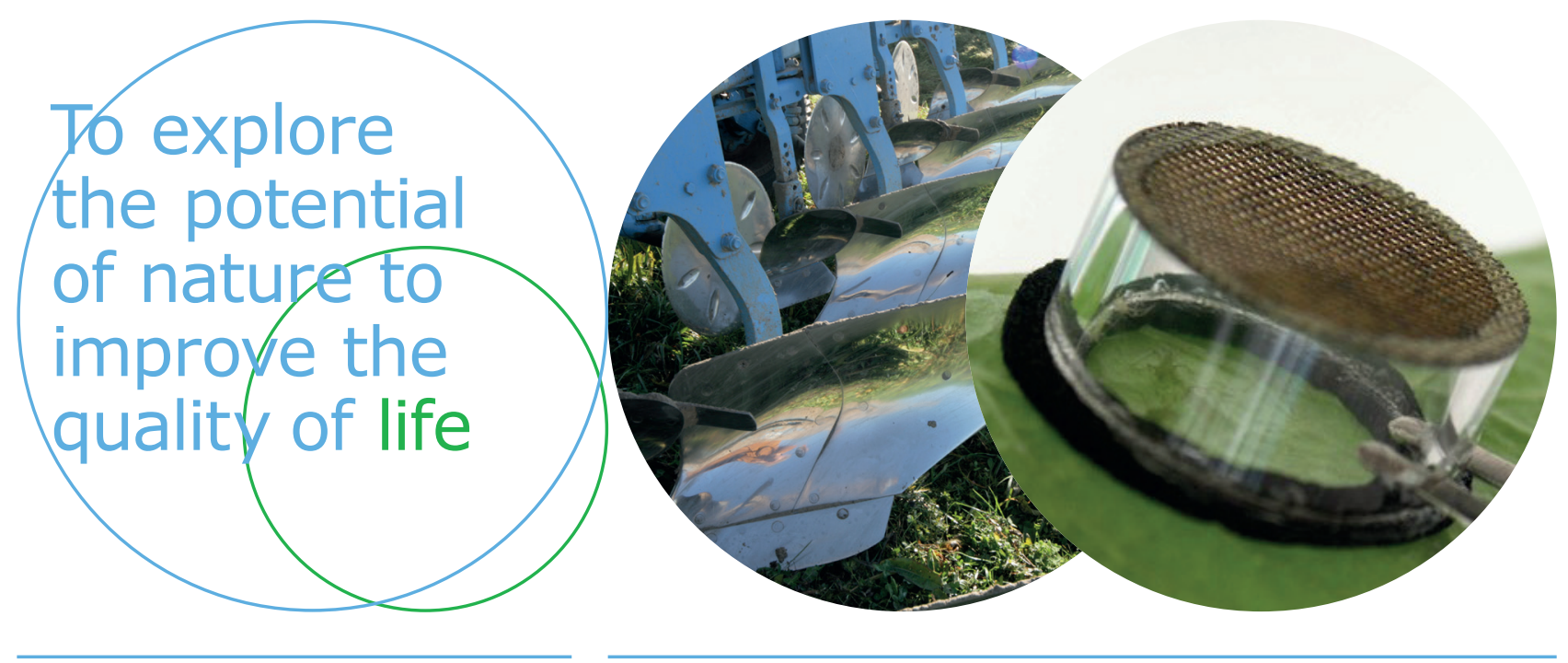

Wageningen University \& Research

\section{Open Teelten}

Edelhertweg 1

Postbus 430

8200 AK Lelystad

T (+31)320 291111

www.wur.nI/openteelten

Rapport WPR-822
De missie van Wageningen University \& Research is 'To explore the potential of nature to improve the quality of life'. Binnen Wageningen University \& Research bundelen 9 gespecialiseerde onderzoeksinstituten van stichting DLO en Wageningen University hun krachten om bij te dragen aan de oplossing van belangrijke vragen in het domein van gezonde voeding en leefomgeving. Met ongeveer 30 vestigingen, 6.000 medewerkers en 9.000 studenten behoort Wageningen University \& Research wereldwijd tot de aansprekende kennisinstellingen binnen haar domein. De integrale benadering van de vraagstukken en de samenwerking tussen verschillende disciplines vormen het hart van de unieke Wageningen aanpak. 